NBER WORKING PAPER SERIES

\title{
IS THE GED AN EFFECTIVE ROUTE TO POSTSECONDARY EDUCATION FOR SCHOOL DROPOUTS?
}

\author{
John H. Tyler \\ Magnus Lofstrom \\ Working Paper 13816 \\ http://www.nber.org/papers/w13816 \\ NATIONAL BUREAU OF ECONOMIC RESEARCH \\ 1050 Massachusetts Avenue \\ Cambridge, MA 02138 \\ February 2008
}

The authors wish to thank Thomas Dee, Brian Jacob, Martin West, Richard Murnane, and Heather Rose for helpful comments on an earlier draft of this paper. The views expressed herein are those of the author(s) and do not necessarily reflect the views of the National Bureau of Economic Research.

NBER working papers are circulated for discussion and comment purposes. They have not been peerreviewed or been subject to the review by the NBER Board of Directors that accompanies official NBER publications.

(C) 2008 by John H. Tyler and Magnus Lofstrom. All rights reserved. Short sections of text, not to exceed two paragraphs, may be quoted without explicit permission provided that full credit, including $\odot$ notice, is given to the source. 
Is the GED an Effective Route to Postsecondary Education for School Dropouts?

John H. Tyler and Magnus Lofstrom

NBER Working Paper No. 13816

February 2008

JEL No. I2,J18

\begin{abstract}
$\underline{\text { ABSTRACT }}$
We use data from the Texas Schools Microdata Panel (TSMP) to examine the extent to which dropouts use the GED as a route to post-secondary education. The paper develops a model pointing out the potential biases in estimating the effects of taking the "GED path" to postsecondary education. Lacking suitable instruments that would allow us to directly address potential biases, our approach is to base our estimates on a set of academically "at risk" students who are very similar in the 8th grade. We observe that the eventual high school graduates in this group have much better postsecondary education outcomes than do the similar at-risk 8th graders who dropped out and obtained a GED. Our model explains the observed differences, and allows for a discussion of the policy challenges inherent in improving the postsecondary outcomes of dropouts.
\end{abstract}

John H. Tyler

Box 1938

21 Manning Walk

Brown University

Providence, RI 02912

and NBER

john_tyler@brown.edu

Magnus Lofstrom

Public Policy Institute of California (PPIC)

500 Washington Street, Suite 600

San Francisco, CA 94111

lofstrom@ppic.org 


\section{Introduction}

Every year approximately a million students leave high school without receiving a diploma. Based on any indicator, these school dropouts face a bleak prospect in today’s economy. One potentially ameliorating option for dropouts is the acquisition of the General Educational Development (GED) credential. The use of the GED has grown over the years and currently about three quarters of a million people per year try obtain this "second chance” credential. A logical question is: a "second chance” for what? While recent research indicates that acquisition of a GED is associated with increased earnings for some dropouts, ${ }^{1}$ this same research points out that acquiring a GED is no ticket out of poverty for those lacking a traditional high school diploma. At least to the extent that the GED is an education endpoint, this is not a surprising result given what we know about the labor market disadvantages faced by those who lack any postsecondary education. Thus, any serious economic role the GED might play likely lies in the extent to which this credential helps school dropouts move into postsecondary education programs. As it turns out, however, GED acquisition as a route into postsecondary education is a woefully understudied area, especially given the confluence of the rising importance of postsecondary education, increasing concerns over the nation’s “dropout problem,” and the large numbers of dropouts who obtain a GED each year.

This paper addresses this knowledge gap using a unique data set constructed from the Texas Schools Microdata Panel (TSMP) to compare the postsecondary education enrollment outcomes of students who dropped out and obtained a GED and students who remained in school and obtained a high school diploma. Our aim is to provide information on the extent to which pursuing the “GED path” versus the "high school

\footnotetext{
${ }^{1}$ See for example Tyler, Murnane, and Willett (2000) and Tyler (2004).
} 
graduation path” affects postsecondary education (PSE) enrollment. It is important to think about "pathways" to PSE since it is probably not the education credential—GED or high school diploma—per se that affects PSE, but rather factors associated with the journey required to earn these credentials that are important.

Our focus in this paper is on a comparison of the PSE enrollment outcomes of GED holders versus high school graduates rather GED holders versus uncredentialed dropouts. We are less interested in the GED-uncredentialed dropout comparison because the enrollment policies of most two-year and four-year colleges and universities require applicants to have some school leaving credential, particularly in degree-granting programs. ${ }^{2}$ Given higher education enrollment policies, comparing GED holders to uncredentialed dropouts may simply be an examination of the effectiveness of the gate keeping mechanisms of postsecondary education admission and enrollment policies.

A second reason for focusing on the GED-high school graduate comparison has to do with the counterfactual most people may have in mind when they think about the GED-PSE relationship. While there is no empirical evidence, our sense is that many observers wonder what would have happened to GED holders had they somehow been compelled to stay in high school until graduation. Of course, the relevant comparison to answer that question is one between acceptably similar GED holders and high school graduates.

Given our focus, the thought experiment that lies behind our research is the following: if one individual is "assigned" to the dropout/GED route and another identical individual is "assigned" to the high school completion route, would they be equally likely

\footnotetext{
${ }^{2}$ For example, a 1988 National Center for Education Statistics study of a nationally representative sample of postsecondary education institutions indicated that 90 percent of all postsecondary education institutions require some type of "certification” for admission (Hexter and Anderson 1986).
} 
to participate in PSE? Our working hypothesis is that relative to remaining on a path to high school graduation, there is likely no systematic "GED advantage" in terms of PSE participation, and in fact, the GED route may confer disadvantages that inhibit PSE. Thus, for our two hypothetical individuals, we would expect to see either no difference in the probability of PSE enrollment or a lower probability for the individual relegated to the GED path. Determining the extent to which this is the case is the empirical question we pursue in this paper.

Of course, the very tough challenge is constructing suitably comparable groups of GED holders and high school graduates, as there are fierce selection issues at hand. The selection problem potentially starts with the fact that those observed with a GED have first dropped out of school. Subsequent to the dropout decision, a second selection process takes place when individuals in the pool of dropouts make decisions regarding acquisition of a GED. Finally, among those who have the requisite credentials for college enrollment—-that is, within the pool of GED holders and high school graduatesindividuals make selection decisions regarding PSE.

To bring structure to the problem, we model this process. Our model makes explicit the sources of potential bias in Ordinary Least Squares (OLS) estimates and with plausible assumptions allows us to sign the overall bias. Lacking suitable instruments, our approach to addressing bias is to base our estimates on a subsample of students who were academically "at risk" in the $8^{\text {th }}$ grade. While we will not argue that this approach eliminates all bias, we do believe that our estimates have more information content than estimates in past empirical work that has utilized more heterogeneous samples. 
This paper proceeds as follows. After discussing the prior research on the postsecondary outcomes of GED holders, we present our decision model. We then describe the data used in this paper, present our results, and close with a discussion of the possibilities and challenges these results present to policy formulation aimed at using the GED program to improve the postsecondary education attainment of dropouts.

To preview our findings, our results show that GED holders have substantially worse PSE outcomes than do observationally similar high school graduates. As our model will illustrate, however, these negative results could be the result of either unobserved heterogeneity or the persistent effects of random negative shocks that caused students to leave school in the first place. Thus, we urge caution in drawing the inference that, relative to high school completion, the "GED route" is a decidedly inferior route to PSE.

\section{Prior Research}

One of the most robust areas of study in labor economics during the 1990s was the attention given to the rising return to a college degree. One strand in this research area provides evidence that postsecondary education appears to be important even when it does not result in a degree. Kane and Rouse (1995) find that a year of college credit, regardless of degree status, is associated with a 4-7 percent increase in hourly wages and annual earnings. They are unable to reject the hypothesis that credits earned at two-year and four-year colleges are equivalent. This is a particularly important finding for GED holders who go on to postsecondary education since they are much more likely to enroll 
in a two-year institution and much less likely to obtain a degree conditional upon entering college. ${ }^{3}$

NLSY-based evidence in Murnane, Willet, and Boudett (1999) confirm that GED holders do receive an economic benefit from postsecondary education that is equal to the returns experienced by high school graduates. Their estimates of the return on an additional year of college range from 5.2 percent in a random effects specification to 10.8 percent in a fixed effects specification. These estimates are similar to the returns that Kane and Rouse estimated across all enrollees. Taken together, the lessons from these two studies are that postsecondary education is economically beneficial to GED holders even if they are less likely to complete degrees and, if enrolled, more likely to be enrolled in two-year colleges.

Given the estimated benefits that GED holders derive from postsecondary education, what does the literature have to say about how much postsecondary education they get? Basic descriptive analyses across several studies all indicate that dropouts who obtain a GED tend to acquire more postsecondary education than do uncredentialed dropouts, but less than observationally similar regular high school graduates. Berktold et al (1998) use the 1994 National Education Longitudinal Study of 1988 (NELS 88) follow-up to observe the educational attainment two years after high school graduation of individuals who never dropped out of school, individuals who dropped out but received a credential, and dropouts who remain uncredentialed. They find that credentialed

\footnotetext{
${ }^{3}$ For example, using High School and Beyond data, Murnane, Willett, and Tyler (2000) find that eight years after their expected high school graduation date, only 6 percent of GED holders had earned at least one credit in a four-year college versus 24 percent with at least one credit from a two-year college. The same figures for high school graduates were 48 percent and 32 percent at four- and two-year colleges respectively. In the Texas data we use in this paper, we find that as of 2003, individuals who obtained a GED in the middle to late-1990s had four-year and two-year college enrollment rates of 2 percent and 19 percent respectively.
} 
dropouts, relative to uncredentialed dropouts, are much more likely to have postsecondary education. Forty percent of GED holders have some postsecondary education compared to 14 percent of uncredentialed dropouts. Among those with some postsecondary attendance, half of credentialed dropouts enrolled in degree programs (either AA or BA) whereas almost all uncredentialed dropouts enrolled in certificate or other non-credentialed programs. While credentialed dropouts have higher postsecondary attendance rates than uncredentialed dropouts, Berktold et al find their postsecondary attendance lags behind that of traditional high school graduates. Seventy-eight percent of traditional high school graduates had completed some postsecondary education and around three-quarters of this group were enrolled in a degree program. Credentialed dropouts were less likely to be enrolled and, conditional on enrollment, less likely to be in a degree program than high school graduates were.

The descriptive patterns reported by Berktold et al have been confirmed using other survey data. Murnane, Willet, and Tyler (2000) use High School and Beyond to examine the postsecondary attendance of male GED holders. They also find that the postsecondary attendance of credentialed dropouts falls between uncredentialed dropouts and traditional high school graduates. This paper highlights two other important characteristics of the postsecondary experience of GED recipients. GED recipients are much more likely to be enrolled in 2-year community colleges, as opposed to 4 -year colleges ( 6 percent had attended a four-year institution and 24 percent had attended a two-year institution eight years after their expected high school graduation year). They also accumulate very few credits (an average of 12.3 credits earned within eight years 
after their expected high school graduation year). Tyler, Murnane, and Willet (2003) report similar findings for the females in High School and Beyond.

Murnane, Willett, and Boudett (1997) use data from the National Longitudinal Survey of Youth to test whether the acquisition of a GED increases the probability that dropouts will obtain postsecondary education. The authors estimate random effects probit models using longitudinal data on all high school dropouts, and they find that obtaining the GED does increase the probability of college attendance and that the postsecondary gap between uncredentialed and credentialed dropouts grows over time. While it is interesting to compare credentialed and uncredentialed dropouts, this study is most informative about certificate or other non-degree-granting programs since, as reported earlier in this paper, over 90 percent of all postsecondary education institutions require a credential for matriculation.

The most recent work on the topic is an update of the postsecondary outcomes in the NELS 88 data. At the time of their paper, Berktold at al (1998) could look at postsecondary education outcomes approximately two years after the expected 1992 high school graduation date of the $19888^{\text {th }}$ grade cohort in the study. Using the year 2000 follow up survey, Adelman (2006) is able to look an additional six years beyond the 1994 data available to Berktold at al. In his report Adelman finds that eight years after their expected high school graduation date, approximately 85 percent of the regular high school graduates had enrolled at some time in some postsecondary institution, and that about 35 percent had obtained at least a bachelor’s degree by that time. Meanwhile, 52 percent of the GED holders in the sample showed postsecondary education enrollment by 2000, with only one percent of the GED holders holding a bachelor's degree by that time. 
Table 1 gives the complete distribution of education status for high school graduates and GED holders based on the Adelman work. That table shows that six percent of the regular high school graduates had achieved an associate's degree as the highest earned degree, compared to two percent for GED holders. Meanwhile, a slightly higher percentage of GED holders had a certificate as their highest level of postsecondary education relative to the percentage of high school graduates with a certificate as the highest level of postsecondary education (4.9 percent for GED holders versus about 4 percent for high school graduates).

<Table 1 about here>

While informative, the raw comparisons in Table 1 raise as many questions as they answer since we know that GED holders and regular high school graduates differ on many dimensions before students make decisions to leave school or engage in postsecondary education. In this paper, we will first show that these same differences are present among the $8^{\text {th }}$ graders in the Texas Schools Microdata Panel (TSMP) that we will use in our analysis. We will then demonstrate that students designated as being academically "at risk" are very similar in the $8^{\text {th }}$ grade on many dimensions, regardless of whether they will later drop out and obtain a GED, or whether they will eventually graduate from high school. This similarity at $8^{\text {th }}$ grade "baseline" makes the at-risk group a particular advantageous group to study from a research design standpoint. From a policy standpoint, students found to be academically “at risk" in the $8^{\text {th }}$ grade are also a particular interesting and relevant group for studying how individuals on the academic margin use GED attainment and high school graduation as separate paths into postsecondary education. 


\section{A Sequential Decision Model}

We model the route from the pre-high school years to PSE as a sequential three step process that begins with a pool of students who are all in the $8^{\text {th }}$ grade at time $t=0$. In what follows:

- time period $t=1$ is some time period after the $8^{\text {th }}$ grade but before high school graduation or GED attainment when the dropout decision is being made,

- period $t=2$ is a post- $8^{\text {th }}$ grade period where individuals who decided to drop out in period 1 are making decisions about whether or not to pursue a GED credential, and

- $\quad$ period $t=3$ is a post high school graduation and post GED-attainment period in which high school graduates and GED holders are making post-secondary enrollment decisions.

At $t=1$ following the $8^{\text {th }}$ grade, student $i$ in high school and community $j$ is making the decision of whether to dropout $($ Dropout $=1)$ or stay in school $($ Dropout $=0)$ based on the following equation:

$$
\text { Dropout }_{i j}=X_{i j t} \pi^{\prime}+w_{i}+z_{i t}+\tau_{i 1}+v_{i j} \quad \text { Equation } 1 \mid t=1
$$

In this equation:

- $\quad X$ is a vector of observable characteristics of the individual, school, and community,

- $\quad w$ is an unobserved, time-invariant individual fixed effect,

- $z$ is a unobservable, time-varying personal characteristic of the individual,

- $\tau_{1}$ is a one-time, exogenous drop-out-influencing shock that occurs at $t=1$, and 
- $\quad v$ is a well behaved error term.

Given the exogenous nature of $\tau$, we have $\tau \perp w$ and $\tau \perp z$, and we assume that $w$ and $z$ are orthogonal. In this formulation, examples of $w$ associated with dropping out would be permanent low tastes or high psychic costs associated with academic activities, low motivation, persistent time preferences that overvalue the present relative to the future, permanent misunderstanding about the individual returns to schooling, etc. Examples of $\tau$, the one-time shock that might influence the drop out decision would be an unexpected pregnancy, the sudden unemployment of a parent, parental divorce, or death in the family. Examples of $z$ that might influence a Dropout $=1$ decision would be an evolving dislike of and disengagement from academic endeavors such as school, a growing preference for work relative to academic endeavors as a student becomes old enough for full-time work, or an evolving network of friends who implicitly or explicitly discourage academic endeavors.

Among the individuals who decide to drop out rather than stay in school, a second decision regarding whether or not to obtain a GED $($ GED $=1)$ or not $(G E D=0)$ is made at time $t=2$ :

$$
G E D_{i j} \mid(\text { Dropout }=1)=X_{i j t} \tilde{\pi}+\tilde{\gamma} w_{i}+\tilde{\theta} z_{i t}+\tilde{\lambda} \tau_{i 1}+\xi_{i j} \quad \text { Equation } 2 \mid t=2
$$

In Equation 2 the unobserved $w, z$, and $\tau$ terms have coefficients that allow for relationships between these factors and $G E D$ that are different in size and sign than might be the case in Equation 1.

In Equation 2 we also allow for the influence of the exogenous "drop out” shock $\tau_{1}$ that occurred at time $t=1$. As an example, if $\tau_{1}$ at the earlier $t=1$ period was an unexpected pregnancy, then at $t=2$ individual $i$ might still be pregnant or might have a 
young child. If the decision to obtain a GED at $t=2$ is an investment decision that requires the expenditure of time, effort, monetary resources, or opportunity costs, then any persistent effects of a negative shock may negatively influence the decision to invest in obtaining a GED.

At time $t=3$, the focus shifts to the subset of individuals from the original $8^{\text {th }}$ grade population who have either a GED or a high school diploma. In this time period the sub-sample of GED holders and high school graduates (i.e., the sample conditional upon $[($ Dropout $=1 \& G E D=1) \mid$ Dropout $=0])$ decide whether or not to enroll in postsecondary education based on:

$$
P S E_{i j}=\beta G E D_{i j}+X_{i j t} \pi+\gamma w_{i}+\theta z_{i t}+\lambda \tau_{i 1}+\varepsilon_{i j} \quad \text { Equation } 3 \mid t=3
$$

Again, potential persistence of the $t=1$ drop out shock is allowed to influence postsecondary education decisions in this third period, and the unobserved $w, z$, and $\tau$ are allowed to have different relationships to the postsecondary education decision than were their relationships to the drop out and GED decisions in Equations 1 and 2.

The parameter of ultimate interest is $\beta$ in Equation 3, and we would like to interpret estimates of $\beta$ as estimates of the causal effect on PSE enrollment of going through the GED path as opposed to the high school graduation path. As discussed in the introduction, our prior is that $\beta$ is either zero or negative. We begin our discussion of the threats to this interpretation by pointing out that given the unobserved nature of $w, z$, and $\tau_{1}$ the typical equation estimated in the existing GED-PSE literature is given by Equation 3' below (where, as in Equation 3, the estimation is over a sample of GED holders and high school graduates):

$$
P S E_{i j}=\beta G E D_{i j}+X_{i j} \pi+\varepsilon_{i j} \quad \text { Equation } 3^{\prime} \mid t=3
$$


Given Equation 3 and our earlier assumptions regarding the orthogonality of $w, \tau$, and $z$, Ordinary Least Squares (OLS) estimates of $\beta$ based on Equation 3' will yield:

$$
E\left[\hat{\beta}_{O L S} \mid X\right]=\beta+\gamma \frac{\sigma_{G E D, w}}{\sigma_{G E D}^{2}}+\theta \frac{\sigma_{G E D, z}}{\sigma_{G E D}^{2}}+\lambda \frac{\sigma_{G E D, \tau 1}}{\sigma_{G E D}^{2}}
$$

That is, failure to account for the role of time invariant $w$, time-varying $z$, and the persistent effects of $\tau_{1}$ will potentially bias estimates of the GED path to PSE relative to the high school graduation path. In what follows we explore the direction of the overall bias from these three bias terms. In this discussion it will be important to keep in mind the four different time periods, $t=0,1,2$, and 3 , and the fact that in the different time periods we are dealing with different samples of individuals who are making different decisions, and hence the relevant covariances are being considered over different pools of individuals. For simplicity we will call the time periods $t 0, t 1, t 2$, and $t 3$. The samples and relevant decisions across these time periods are:

- $t 0$ : all students are in the $8^{\text {th }}$ grade,

- $t 1$ : in this post- $8^{\text {th }}$ grade period all students are deciding whether to drop out or stay in school,

- $t 2$ : in this period all students who dropped out in $t 1$ are deciding whether to obtain a GED or remain an uncredentialed dropout, and

- $t 3$ : the students who did not drop out in $t 1$ and the dropouts who obtained a GED in $t 2$ are deciding whether to enroll in PSE.

Bias attributable to the time-invariant individual effect $w_{i}$ : 
Assume, without loss of generality, that $w$ is negatively correlated with educational investments. Given the time-invariant nature of $w$, this means that $\gamma<0$ in Equation 3 when individuals are deciding whether to invest in PSE. Furthermore, since eventual GED holders had to first make the dropout decision at $t 1$, it follows that among the pool of GED holders and high school graduates at $t 3, \sigma_{G E D, w} \geq 0$. Thus, the bias attributable to $w$ is either negative or zero. ${ }^{4}$

Bias attributable to the time-varying individual heterogeneity $\mathrm{z}_{i t}$ :

Assume that $z$ is a time-varying trait that is negatively correlated with educational investments, and notice that this means that $\theta<0$ in Equation 3. At $t 1$, eventual GED holders made the decision to dropout when eventual high school graduates did not, suggesting that $\sigma_{G E D, z} \geq 0$ at $t 1$. At $t 2$, within the pool of dropouts, some make the decision to invest in a GED suggesting that $\tilde{\theta} \leq 0$ in Equation 2. At $t 3$, GED holders and high school graduates are making the PSE enrollment decision, and the sign on $\sigma_{G E D, z}$ at this time is not obvious. It could be that the elements of $z$ correlated with the dropout decision at $t 1$ are still present during the time to make PSE enrollment decisions and thus $\sigma_{G E D, z} \geq 0$ at $t 3$.

On the other hand, the GED holders at $t 3$ are those dropouts who decided to invest in the GED at $t 2$. Thus, it could be that, all else equal, GED holders at $t 3$ have less of the trait $z$ that is negatively related to PSE-investment than do high school graduates yielding $\sigma_{G E D, z} \leq 0$ at $t 3$. While it is plausible that $\sigma_{G E D, z}=0$ at $t 3$, we find it unlikely that GED

\footnotetext{
${ }^{4}$ Notice that if we had assumed that $w$ was positively correlated with education investments the signs of the two factors in the $w$ bias term would be switched and the bias attributable to this term would still be negative or zero.
} 
holders have less $z$ that do high school graduates (i.e., $\sigma_{G E D, z}<0$ ). Therefore, given the expected negative sign on $\theta$ in Equation 3, we find the most likely bias attributable to $z$ to be either negative or zero.

Bias attributable to persistent effects from the negative drop out shock $\tau_{1}$ :

If students left school in $t 1$ because of a negative shock, it could be that the effects of that shock are still present and affecting PSE decisions in $t 3$. If these shocks are persistent then $\sigma_{G E D, \tau l} \geq 0$ and $\lambda<0$ in Equation 3, and the bias attributable to $\tau_{l}$ is either zero or negative.

In summary, it is likely that the overall OLS bias is negative. Given our hypothesis that true $\beta$ is either negative or zero, this means that negative estimates of the "GED effect" on PSE should be interpreted as lower bounds on a negative effect. Therefore, the estimates that we, and previous research, present may well overstate any negative effects of taking the "GED route" to PSE, and without eliminating the OLS bias, one could not rule out an inference that there is no negative "GED effect" on PSE.

Lacking any suitable instrumental variables that might allow us to address the potential bias, one way to reduce the bias is to define a sub-sample of GED holders and high school graduates who tend to be more homogeneous than is the case in the general population of GED holders and high school graduates. Seizing on this opportunity, we will use a subsample of students who are academically "at risk" just prior to high school entry in the $8^{\text {th }}$ grade. For narrative simplicity, we will call this subsample of $8^{\text {th }}$ grade atrisk students the AR8 sample, and we will show that in the $8^{\text {th }}$ grade, eventual GED 
holders and eventual high school graduates in this sample were very much alike on key dimensions, including test scores.

Aside from their similarity to eventual high school graduates, a particular advantage of using the AR8 sample for our purposes has to do with the potential heterogeneity within the GED population, and the implications of this heterogeneity for some key assumptions in our model. In particular, Heckman and Rubinstein (2001) find that the average student who drops out and obtains a GED is close to the average high school graduate in terms of academic ability, but that the average GED holder has substantially worse non-cognitive traits than the individuals who complete high school. In the terms of Heckman and Rubinstein, these GED holders are the "wise guys" in class who could make it academically, but who are unable to function in a school environment because of their poor non-cognitive skills. A concern for us is that these academically able "wise guys" who end up with a GED do not view the decisions we have modeled at times $t 2$ and $t 3$ as education investment decisions. In terms of the model, our concern is that $\sigma_{G E D, w}^{\text {wise guy }}<\sigma_{G E D, w}^{A R 8}<0$ and $\sigma_{G E D, z}^{\text {wise guy }}<\sigma_{G E D, z}^{A R^{*}}<0$ at $t 3$, and that any negative OLS bias is worse with these academically strong but non-cognitively weak individuals than without them. Thus, by using the AR8 group we potentially reduce the negative bias in the OLS estimator and we have a group of individuals for whom our modeling assumptions regarding education investment decisions are more likely to hold.

\section{Data and Samples}

Our study uses TSMP data to examine the postsecondary outcomes of students who, by age, were in the cohort that should have been in the $8^{\text {th }}$ grade in the spring of 
1994, and thus scheduled to graduate in the spring of 1998. In particular, we will examine the AR8 subset of this cohort. The "at risk" indicator in our data used to construct the AR8 sample is a variable in the TSMP data based on a designation generated by the Texas Education Agency (TEA). When our sample was in the $8^{\text {th }}$ grade, Texas school districts were required to report a student as academically “at risk” of dropping out or failing if any of the following criteria were met. ${ }^{5}$ The student...

1. was not advanced from one grade level to the next for two or more school years;

2. is at least two years below grade level in reading or mathematics;

3. has failed at least two courses and is not expected to graduate within four years of entering ninth grade;

4. has failed at least one section of the most recent state assessment exam; or

5. is pregnant or is a parent.

Relative to other potential data, the TSMP data present several advantages in a study of the GED-PSE relationship. First, all of the K-12 information in the TSMP is from administrative records collected by schools and school districts rather than from self reports of students, teachers, or parents. Likewise, the postsecondary education information we will use for our dependent variables is from state higher education administrative records. Second, the TSMP data contain information from the state assessment program, the Texas Assessment of Academic Skills (TAAS), a high stakes test for public school students in Texas. Third, schools in the TSMP can be linked to the U.S. Department of Education's Common Core of Data data files. We use this feature of

\footnotetext{
${ }^{5}$ According to the "1996-97 Report on High School Completion Rates" (Texas Education Agency) the source for this definition is Texas Education Code $§ 29.081$.
} 
the TSMP to control for school-level variables of both the school of attendance in the $8^{\text {th }}$ grade and the last school of attendance before a student drops out or graduates from high school. Fourth, the "at risk" designation in the TSMP for our $8^{\text {th }}$ grade students is based upon an objective, state-level definition that utilizes information from a student's entire prior educational experience. Finally, the sample size available is substantially larger than is available in, for example, NELS 88. In that data set there are approximately 11,000 high school graduates and 800 GED holders available for study. In the $19948^{\text {th }}$ grade cohort of the TSMP data that we use there are over 142,000 high school graduates and 6,000 GED holders. The analytic data set constructed for this paper uses all of the GED holders in the TSMP data and a random twenty percent (one in five) of the high school graduates. All standard errors are adjusted accordingly.

We focus our study on the $19948^{\text {th }}$ grade cohort of the TSMP because this group best capitalizes on two features of the TSMP data that are important to this study: good $8^{\text {th }}$ grade data and data on postsecondary education outcomes after these students have graduated from high school or obtained a GED. While the TSMP has data on Texas schoolchildren from 1990 to the present, the state TAAS examinations were first given to $8^{\text {th }}$ graders in Texas in 1994, hence our focus on the group that was age appropriate for the $8^{\text {th }}$ grade in 1994 . The postsecondary education files in the TSMP data contain information on all enrollments and number of "enrolled credits" at public postsecondary education institutions in Texas through 2002 and information on awarded postsecondary degrees and certificates at these institutions through $2003 .{ }^{6}$ Our method in using these data will be to allow a three-year window for examining enrollments and credits, and a

\footnotetext{
${ }^{6}$ By "enrolled credits," we mean that we have information on the number of credits in which a student was enrolled in a given year, but we do not have information on the number of those credits that were completed and received a passing grade.
} 
four-year window for examining earned degrees and certificates. The window for each student in the sample will begin after either high school graduation or after GED acquisition. Thus, one sample selection criterion is that a member of the 1998 graduation cohort had to have graduated from high school or obtained their GED no later than 1999 to be included in our analysis. Within the AR8 sample in the TSMP, 69 percent graduated from high school, 7 percent had dropped out and obtained a GED by 1999, and 20.5 percent had dropped out and had no GED as of 1999. An additional 2.5 percent got their high school diploma between 1999 and 2001, and additional 0.9 percent obtained a GED in this post-1999 period. The comparable figures for members of the $19948^{\text {th }}$ grade cohort who were not labeled as "at risk" are 86 percent high school graduates, 6 percent GED holders, and 7 percent uncredentialed dropouts as of 1999, with 0.9 and 0.6 percent receiving a high school diploma or GED post-1999, respectively.

Appendix Table A1 shows the results of this and other sample selection decisions we made in forming our AR8 analytic sample. As this table shows, there were 12,358 eligible eventual GED holders, of whom 6,520 were in the at-risk category in the $8^{\text {th }}$ grade, and 28,538 eventual high school graduates, of whom 11,937 were designated as atrisk $8^{\text {th }}$ graders.

As row seven in Table A1 shows, the decision to use only those who graduated or received their GED by 1999 affects the GED sample more than the high school graduate sample, as the GED sample drops by 10 percent and the high school graduate sample drops by only three percent on this decision. To examine the potential impact of this sample selection decision, we used the middle years of the available TSMP data (expected graduation cohorts of 1994, 1995, and 1996) to study the distribution of GED 
acquisition dates relative to expected graduation date. We use these middle cohorts since they have the most opportunity in the TSMP data for either early or late GED acquisition dates relative to their expected high school graduation year. Depending on the cohort, we find that between two-thirds and three-quarters of the GED holders in the 1994, 1995, and 1996 expected-graduation cohorts obtained a GED before, on, or within one year after their expected high school graduation date. We then use these data to examine the TAAS scores of individuals who obtained their GED more than one year after their expected graduation date. This examination shows that these "late GED” individuals had $8^{\text {th }}$ grade TAAS math scores that were a third of a standard deviation lower than the GED holders who acquired this credential before, on, or one year after their expected graduation year. Thus, by not using these "late GED” individuals our sample will tend to be composed of the most academically able GED holders in the AR8 sample, conditional on being at-risk in the $8^{\text {th }}$ grade. Since these individuals are more likely to engage in postsecondary education, we expect that our estimates will be upwardly biased relative to what we would find if we were able to include the "late GED” individuals in our study.

Before turning to our AR8 sample, we use Appendix Table A2 to illustrate the comparability of the TSMP to data that has been used in prior work. We first point out that individuals who will drop out and obtain a GED have $8^{\text {th }}$ grade math scores that are about a third of a standard deviation lower than those of $8^{\text {th }}$ graders who will go on to become high school graduates, and $8^{\text {th }}$ grade reading scores that are a quarter of a standard deviation lower. A higher percentage of the eventual GED holders are male, white, and "economically disadvantaged,"7 and they tended to go to school in urban areas more than was the case for eventual high school graduates. The GED holders were more

\footnotetext{
${ }^{7}$ Students who are eligible for free or reduced price lunch are defined to be economically disadvantaged.
} 
likely to have started first grade late or to have been held back prior to the $8^{\text {th }}$ grade, and a higher percentage of them were in the "at risk" category in the $8^{\text {th }}$ grade. ${ }^{8}$ On the other hand, the eventual GED holders and eventual high school graduates tended to go to $8^{\text {th }}$ grade schools that had similar characteristics.

Not surprisingly, some of the biggest differences in the two groups appear in their postsecondary education outcomes. Within the three-year window that we allow for postsecondary education, high school graduates were much more likely to have ever enrolled in a public Texas postsecondary education institution (58.5 percent versus 22.4 percent for GED holders), more likely to have earned a postsecondary certificate or associate’s degree, and they had enrolled for more credits in the three years after graduation than the GED holders. ${ }^{9}$ We note that the patterns of postsecondary education attainment in Table A2 are similar to those using NELS data in Table 1. The higher attainment figures in Table 1 for all groups reflect the fact that those data allow for a sixyear window for the high school graduates and longer for GED holders who obtained their GED prior to 1994.

In summary, the patterns in the TSMP data are similar to those consistently found in the literature across time and across different data sets. Namely, GED holders have worse postsecondary education outcomes than regular high school graduates, but GED holders are also systematically different from high school graduates on observable factors

\footnotetext{
${ }^{8}$ Our examination of $8^{\text {th }}$ graders in the NELS data set yields some similarities and differences to what is seen in the TSMP data. Importantly, $8^{\text {th }}$ grade test score differences between eventual GED holders and high school graduates are very similar across the different data sets. Not surprisingly, in the Texas data a higher percentage of both GED holders and high school graduates are Hispanic than is the case in the NELS data. The NELS data are more balanced on gender across the two education groups than in the TSMP, and there is a greater discrepancy in the percent who are at-risk in the $8^{\text {th }}$ grade in NELS, 66 percent of the eventual GED holders versus 37 percent of the eventual high school graduates.

${ }^{9}$ Because of the low enrollment rates of GED holders in four-year colleges versus two-year colleges referenced earlier in this paper, we will focus our study on enrollment and credits in either a two-year or a four-year college.
} 
that tend to correlate with postsecondary education attainment. In particular, like other researchers, we find substantial differences in the underlying academic achievement of eventual GED holders and eventual high school graduates. ${ }^{10}$

Given the importance of early academic achievement on later postsecondary education attainment, we want to examine more closely the $8^{\text {th }}$ grade TAAS test scores in the TSMP data. To do this we first account for the fact that delayed first grade entry or being held back a grade at some point means that not all students take the $8^{\text {th }}$ grade TAAS exams in the same year and hence at the same age. In the $19948^{\text {th }}$ grade cohort about 73 percent of the eventual GED holders took the $8^{\text {th }}$ grade TAAS tests in 1994, 25 percent took these exams in 1995, and 2 percent took the exams in 1996. Meanwhile, 83 percent of the eventual high school graduates took the exams in 1994, 16 percent in 1995, and one percent 1996. To account for any age effects on the TAAS scores we use the residuals from a regression of the TAAS scores on year-of-test dummies and then standardize the residuals to have a mean of zero and a standard deviation of one. ${ }^{11}$ Relative to non-age-corrected mean test scores reported in Appendix Table A2, the differences between GED holders and high school graduates are slightly smaller when using these age-corrected scores. Nevertheless, the age-corrected math scores of eventual high school graduates are still about one-fifth of a standard deviation higher than are those of eventual GED holders, and the high school graduate reading scores are about one-eighth of a standard deviation higher.

\footnotetext{
${ }^{10}$ An exception to this pattern is that Heckman and Rubinstein (2001) find that in then NLSY79 the ageadjusted AFQT scores of GED holders and high school graduates are similar.

${ }^{11}$ Of course, in correcting for the age at which an individual took the $8^{\text {th }}$ grade TAAS tests, we are also correcting for anything else that is related to why an individual may have taken the TAAS scores in a later year than expected given their age.
} 
Of course, mean comparisons only present a partial picture of the comparability of groups on a measure such as test scores. Figures 1 and 2 provide more information on these age-corrected and standardized $8^{\text {th }}$ grade test scores, as these figures present the entire distributions of the math (Figure 1) and reading (Figure 2) scores for GED holders and high school graduates. Figures 1 and 2 also present the test score distributions of two other groups not yet discussed: $8^{\text {th }}$ graders who eventually dropped out of high school and never attempted the GED through 2003, and $8^{\text {th }}$ graders who dropped out and attempted, but failed the GED exams sometime before 2003. These test-score distributions make it clear that in the $8^{\text {th }}$ grade there are already underlying academic differences between students who will later sort themselves or be sorted into different educational credential groups. Figures 1 and 2 also make it clear that comparing the later outcomes of GED holders and regular high school graduates may be a tenuous proposition because these groups are already substantially different academically in the $8^{\text {th }}$ grade.

$<$ Figures 1 and 2 about here $>$

We turn next to the AR8 sample that we will use in the empirical work. As discussed early, to the extent that this group is more homogeneous in $w$ and $z$, estimates based on the AR8 sample should reduce any negative bias in the OLS estimator of Equation 3'. We also note that "at risk" students are an especially policy relevant group when it comes to questions of how dropouts use the GED to access postsecondary education. Not only are at-risk students often a focus of policy interest, but these are students for whom it is more likely that a negative life or school event will prove be the proverbial "straw that broke the camel's back," leading to a decision to drop out of school. In terms of our model, it may be that within the AR8 sample it is more likely that 


$$
\left|\sigma_{G E D, \tau 1}\right|>\left|\sigma_{G E D, w}\right| \quad \text { and } \quad\left|\sigma_{G E D, \tau 1}\right|>\left|\sigma_{G E D, z}\right| \text {, }
$$

and thus more likely that the primary source of any bias in the OLS estimator comes from the persistent negative effects of the random $t 1$ shock rather than from unobserved heterogeneity. Of course, we cannot bring direct evidence on the extent to which GED holders and high school graduates are more similar in $w$ and $z$ in the AR8 sample than in the general population. We can show, however, that on observable dimensions including test scores, GED holders and high school graduates in the AR8 sample were very similar in the $8^{\text {th }}$ grade.

Figures 3 and 4 give the same test score distributions as Figures 1 and 2 except that only at-risk $8^{\text {th }}$ graders are used to generate the distributions. While the dropouts who never attempt or attempt and fail the GED still look very different from the eventual GED and high school graduate groups, these latter two groups now have virtually identical $8^{\text {th }}$ grade test score distributions in both math and reading. There are statistically significant, though substantively small, differences in the means of the GED and high school graduate distributions, but interestingly, they favor the eventual GED holders. Among these at-risk students, eventual GED holders have mean $8^{\text {th }}$ grade math scores that are 0.03 of a standard deviation higher than eventual high school graduates ( $\mathrm{p}$-value $=0.03$ ) and reading scores that are 0.08 of a standard deviation higher (p-value $<0.00$ ).

$<$ Figures 3 and 4 about here $>$

Of course, at-risk students are a relatively more homogenous subset of all $8^{\text {th }}$ grade students and so it is not overly surprising that test score distributions of eventual GED holders and eventual high school graduates in the AR8 sample would be more similar than in the pool of all $8^{\text {th }}$ graders. Figures 5 and 6 illustrate that stratification 
along at-risk status is not in and of itself the driving force behind the similar GED-high school graduate test score distributions. These figures display GED and high school graduate test score distributions by at-risk status and illustrate that among future GED holders and high school graduates, the distributions in the AR8 sample are much more similar than those based on a sub-sample of "not-at-risk" students. ${ }^{12}$

$<$ Figures 5 and 6 about here $>$

\section{Descriptive Statistics}

Descriptive statistics of the AR8 sample are in Table 2. While most GED-high school graduate differences are statistically significant because of our large sample size, there are few mean differences between these groups that are large enough to be of substantive importance. The most substantial differences are that the eventual GED holders are more likely to be male, white, and to have been "late" arriving at the $8^{\text {th }}$ grade relative to their cohort. Meanwhile, they are less likely to be black, in special education in the $8^{\text {th }}$ grade, and enrolled in an English Second Language (ESL) program than are the eventual high school graduates. There are some statistically significant differences in the schools attended by the two at-risk groups when they were $8^{\text {th }}$ graders, but again, these differences are all substantively small. Nevertheless, one would want to control for the observable differences in the two groups when making comparisons of postsecondary education outcomes.

\footnotetext{
${ }^{12}$ Turning to NELS data again, we see very similar patterns. Within the at-risk pool in NELS, eventual GED holders have math scores that are only 0.05 of a standard deviation lower than high school graduates and this difference is not statistically significant (p-value $=0.40$ ). Meanwhile, in the not-at-risk pool in NELS, the math score difference between the two groups is 0.42 of a standard deviation in favor of the high school graduates and significant at the 0.001 level. These general patterns are the same for reading scores in NELS. Reproducing the graphs in Figures 5 and 6 based on NELS data shows the same convergence of the GED and high school graduate test score distributions in the at-risk pool, though the convergence is not as complete as in the TSMP data.
} 
$<$ Table 2>

We now turn to these comparisons. Table 3 gives the means of the postsecondary education outcomes that we will examine. This table not only provides postsecondary education information for the AR8 sample, but for the sake of comparison, it also presents information for the eventual GED holders and high school graduates who were not categorized as “at risk" in the $8^{\text {th }}$ grade.

Panel A in Table 3 provides statistics based on everyone in each group. The postsecondary education statistics in Panel B are all conditional on having been enrolled in postsecondary education at some point. The first column of Table 3 gives us a first look at how eventual GED holders in the AR8 sample use the GED credential to access postsecondary education. Three years after obtaining a GED, only 18 percent had ever enrolled in a public postsecondary institution in Texas, and less than one percent had earned either a postsecondary education certificate or an associate’s degree. Furthermore, these at-risk GED holders had enrolled for only 5.5 total credits on average during the first three years after obtaining a GED. The companion statistics in Panel B are a bit more encouraging. Individuals who had ever enrolled in postsecondary education enrolled in an average of about 30 credits within the first three years of receipt of the GED. That is, the average enrollee had enrolled for about a year's worth of credits in the three years following receipt of the GED. These enrolled credits rarely translated into either a certificate or an associate's degree, however, as only 1.8 and 1.2 percent of the students who had been enrolled had earned a certificate or associates degree, respectively, within the first four post-GED years.

$<$ Table 3 about here $>$ 
The figures in the first column of Table 3 can be put in some context by comparing them to the outcomes of eventual high school graduates in the AR8 sample. Almost half of these students (46 percent) had enrolled in some form of postsecondary education three years after graduation, and the mean number of enrolled credits was about 22, four times as many as for the AR8 GED holders. Meanwhile, about four percent of these high school graduates had earned either a certificate or an associate's degree. Conditional on having ever been enrolled, high school graduates had more enrolled credits, were more likely to earn a certificate, and were much more likely to have earned an associate’s degree.

Not surprisingly, within education credential group all of the outcomes for the not-at-risk students in the last two columns are better than those for the AR8 students in the first two columns. It is striking, however, that the at-risk high school graduates, represented in the second column, have substantially better postsecondary education outcomes than do GED holders who were not at-risk $8^{\text {th }}$ graders (third column). In particular, the high school graduates are much more likely to have ever been enrolled (46 percent to 27 percent). Even among those who had positive enrollment figures, the at-risk graduates have substantially better postsecondary education outcomes than GED holders who were not "at risk" in the $8^{\text {th }}$ grade.

\section{Conditional Estimates of Postsecondary Education Outcomes}

We have shown that in the $8^{\text {th }}$ grade, at-risk students have very similar test score distributions regardless of whether they will later drop out and get a GED or graduate with a high school diploma. Thus, if $8^{\text {th }}$ grade academic achievement explains most of the 
variation in later postsecondary education outcomes, the unconditional estimates of the at-risk groups in Panel A of Table 3 should be good estimates of the mean postsecondary education outcomes of the two at-risk groups. On the other hand, Table 2 indicates some small differences between eventual GED holders and high school graduates, and one would want to account for these factors when contrasting the postsecondary education outcomes of these two groups. To this end, we will estimate conditional mean differences based on models that control for:

- gender and race/ethnicity,

- $8^{\text {th }}$ grade variables at the individual level that include age at $8^{\text {th }}$ grade, whether or not economically disadvantaged, and whether or not in special education, an ESL program, or a gifted and talented program,

- $8^{\text {th }}$ grade school-level variables from the Common Core of Data that include total number of students in the school, urbanicity of school location, average pupil teacher ratio in the school, separate variables for the percentage of white, black, Hispanic, and students on free or reduced lunch in the school,

- Common Core of Data information from the last school that the student attended before graduating or dropping out that is parallel to the variables we use for the $8^{\text {th }}$ grade school of attendance, and

- district fixed effects.

Table 4 shows our estimates from a series of nested models using the groups of control variables detailed above. Each column gives three different estimates of the "GED effect" on PSE outcomes, where each of the three regressions in each column has 
the same set of control variables but a different dependent variable. For example, the estimates in the first row are from regressions where the dependent variable is an indicator of whether an individual ever enrolled in a two- or four-year public postsecondary institution in Texas within the first three years of receiving a GED or high school diploma. The second dependent variable (second row) is the total number of credits in which the individual had enrolled in the first three post-credential years. Because of the low percentage of at-risk students who garner either a postsecondary certificate or an associate's degree, we create the third dependent variable (third row) by combining these two outcomes into a single dependent variable: whether or not an individual received either a certificate or an associate's degree within the first four postcredential years.

$<$ Table 4 about here $>$

All estimates are from models fit with Ordinary Least Squares (OLS) with robust standard errors clustered at the district level reported. ${ }^{13}$ Model 1 in Table 4 controls only for $8^{\text {th }}$ grade school district fixed effects. The similarity of the estimated high school graduate-GED differences in postsecondary education outcomes from Model 1 relative to the unconditional estimates in Table 3 suggest that it is not going to be very important to control for $8^{\text {th }}$ grade district fixed effects. In addition, the estimates in the three regressions change very little when controls for gender and ethnicity are added in Model 2.

When individual level $8^{\text {th }}$ grade variables are added, the "GED disadvantage" in ever being enrolled drops by about 15 percent, and the disadvantage in terms of

\footnotetext{
${ }^{13}$ We obtain essentially identical results when using probit instead of OLS linear probability models to fit the data when the two dichotomous variables are dependent variables in the model.
} 
accumulated credits drops by about five percent. In analysis not shown here, examination of these individual-level $8^{\text {th }}$ grade controls shows that by far the most important variable in explaining the GED-high school graduate differences is the age at which an individual enters the $8^{\text {th }}$ grade. Entering the $8^{\text {th }}$ grade late, either from being held back prior to the $8^{\text {th }}$ grade or because first grade was entered late, is negatively correlated with postsecondary enrollment, and a higher percentage of GED holders tend to enter the $8^{\text {th }}$ grade late (28 percent of the at-risk GED holders compared to 22 percent of the eventual high school graduates who were at-risk in the $8^{\text {th }}$ grade).

There are few changes in the estimates as we add $8^{\text {th }}$ grade school-of-attendance and last-school-of-attendance controls in Models 4 and 5. In Model 6 we add a control for whether or not a student was held back at some point between grades 9 through 12 . There are 334 students for whom we lack the data required to construct this variable; hence, the reduction in sample size between Models 1-5 and Model $6 .{ }^{14}$ When this indicator of being held back in high school is included in Model 6, the point estimates of the postsecondary education "GED disadvantage” all fall to between two-thirds to threequarters of the Model 5 estimates. This result is being driven by the fact that students who are retained in high school are much less likely to participate in later postsecondary education, and GED holders are held back at higher rates in high school than are eventual high school graduates. ${ }^{15}$ Our examination of the data show that 53 percent of the at-risk GED holders were held back at some point in high school before they dropped out, while only 14 percent of the at-risk high school graduates were held back at some point in

\footnotetext{
${ }^{14}$ We note that the estimates based on the Models 1-5 specifications are essentially unchanged if fit on the same sample as used in Model 6.

${ }^{15}$ For example, the coefficient estimate on the "held back in high school" dummy variable in Model 6 is 0.20 and highly statistically significant when the dependent variable is "ever enrolled in postsecondary education."
} 
grades 9-12. Given the impact on the estimates of including this indicator of high school retention, a closer look at this phenomenon is warranted.

Table 5 provides the distribution of retained grades for those ever retained in a grade while in high school. We note two facts in Table 5. First, in keeping with the literature on grade retention, the largest percent of students ever retained repeat the $9^{\text {th }}$ grade. Second, we have to remember that the lower percentages of GED holders who are retained in the later grades relative to high school graduates reflects, at least in part, the fact that fewer numbers of these students make it to these latter grades because they have already dropped out.

$<$ Table 5 about here $>$

Table 6 provides an interesting look at the unconditional relationships between education credential status (GED or high school graduate), being retained in high school, and later postsecondary education. First, students who were held back for at least one grade while in high school had worse postsecondary education outcomes than students who were never held back, regardless of education credential status. It is worth noting, however, that the retention-postsecondary education relationships are substantially different for GED holders than for high school graduates. Relative to those who were never held back a grade in high school, ever-retained high school graduates were half as likely to have enrolled in postsecondary education (23.6 percent versus 49.9 percent), about a fifth as likely to have earned a certificate or associate’s degree (1.4 percent versus 4.9), and they had enrolled in a third as many credits (7.4 mean credits versus 24.3). Meanwhile, retained GED holders did have worse postsecondary education outcomes 
than never-retained GED holders, but the differences are not nearly as large as is the case for the high school graduates.

$<$ Table 6 about here>

One way to summarize the relationships between education credential status and high school retention status is to refit Model 6 from Table 4 and include a GED by high school retention interaction. Table 7 gives the results from such a regression for each of the three different postsecondary education outcomes we study. Using the estimates in the first column of Table 7 as an example, there are three comparisons of interest. First, the coefficient estimate on the "retained in high school" variable indicates that eventual high school graduates who were held back at some point while in high school have a 23 percentage point lower enrollment rate in postsecondary education than do high school graduates who were never held back. Meanwhile, the estimated coefficient on the "GED" indicator suggests that GED holders who were never held back have a 24 percentage point lower enrollment rate than high school graduates who were never retained. In the comparison between GED holders who were retained and eventual high school graduates who were retained, the GED disadvantage is much smaller, an enrollment rate that is 8.5 percentage points lower $(-0.243+0.158)$. This general pattern holds across the other two dependent variables in Table 7. In summary, the lessons of Table 7 are:

1. Students retained while in high school have worse postsecondary education outcomes than students never retained regardless of education credential status. 
2. GED holders consistently obtain less postsecondary education than do high school graduates whether looking within the retained-in-high-school category or in the not-retained group.

3. GED holders and high school graduates who were held back at some point in high school tend to look more like each other than do GED holders and high school graduates who were never retained.

4. However, the groups with the most similar outcomes are GED holders who were never held back and high school graduates who were retained at some point between the $9^{\text {th }}$ and $12^{\text {th }}$ grades.

$<$ Table 7 about here $>$

Observation 4 above brings up an interesting point. It could be that the relevant decision facing students who are about to be held back while in high school is whether to repeat the grade and persist to graduation or “cut one’s losses” and drop out now and get a GED. If one thought that most of the GED holders in the not-retained-in-high-school group actually faced grade retention but opted to drop out instead, then the comparisons with the high school graduates who were held back at some point between the $9^{\text {th }}$ and $12^{\text {th }}$ grades is compelling evidence that the dropout-GED decision was not so bad. On the other hand, it may be that few of the never-retained GED holders ever faced high school retention and therefore the retained high school graduates are not a particularly good comparison group. An examination suggests this is the case. In the $8^{\text {th }}$ grade eventual GED holders who were never retained in high school had math and reading scores that were both about two-thirds of a standard deviation higher than the scores of eventual high school graduates who were retained in high school. 


\section{Special GED Subsamples}

As a final exercise, we look at four subsamples of the at-risk GED group, where each group is comprised of GED holders for whom the GED-postsecondary education relationship might be substantively different than for the random GED holder in the atrisk group. The first group of dropouts for whom the GED might be particularly important are those students who have made it most of the way through high school, but who, for whatever reason, drop out in their last years of high school without graduating and receiving a diploma. These students ostensibly have most of the benefits of the high school experience that might be important for positive postsecondary education outcomes since they almost finished high school. Perhaps the GED is a more important "gateway" to postsecondary education for these "late dropouts" who may have garnered most of the human and social capital associated with the high school experience than for those who leave school earlier.

The second group we consider is composed of GED holders from the at-risk group who obtained their GED within one year of dropping out of school. It might be that

dropouts who obtain their GED quickly are more prone to use the credential for accessing postsecondary education than it typically the case. For example, this group might contain a disproportionate number of students who either left high school because they felt they were already prepared for postsecondary education or because they felt the quality of their high school education was very low and would not further prepare them for postsecondary education. Or, even among students who left high school for reasons unrelated to any ex ante desire for postsecondary education, obtaining a GED quickly 
after dropping out may reflect a desire to "stay on track" toward postsecondary education as might have occurred had the student not dropped out.

The third group we consider is composed of those at-risk GED holders who scored in the upper quartile of the GED exams. It may be that the most academically able GED holders disproportionately use the credential to access postsecondary education. To explore this possibility, we form this "high scoring" subsample by using individuals who scored in the upper quartile in terms of their average score over the five tests that make up the GED exams: reading, writing, science, social studies, and mathematics.

The final group we consider is composed of GED holders whose last school of attendance before dropping out was a large urban high school. If these schools are disproportionately of poor quality, then some dropouts in these schools may systematically reason that they are better off to leave a low quality high school before graduation, obtain a GED and then move directly on to postsecondary education rather than spend more time in high school. The sample used to explore this question is comprised of those individuals who attended a large high school in a large central city. We define a "large" school to be one with a student body larger than 2,004 students, the median student body size for a large central city high school in our data. For this analysis only we limit not only the GED sample, but we also limit the comparison group to only those high school graduates who graduated from large high schools in large central cities.

The estimates based on these four different samples are in Table 8. The first column of Table 8 is the examination of "late dropouts," those GED holders who attended at least the $11^{\text {th }}$ grade before dropping out. Out of the 6,520 total at-risk GED holders, 2,220 attended at least the $11^{\text {th }}$ grade before they dropped out. However, in spite 
of the advantage of the extra years of high school relative to earlier dropouts, the "late dropouts" did not have better postsecondary education outcomes than the full sample of GED holders that we have seen in earlier estimates.

The second column of Table 8 presents the estimates for GED holders who obtained their GED within one year of dropping out. Again, these estimates are little different from the estimates of Model 5 in Table 4. In fact, looking across the other columns, we see no real differences in the estimates for these special GED subsamples relative to the fully specified model (Model 5) that uses the entire GED sample.

Separate regressions using only white, black, Hispanic, male, and female samples were also fit using the fully specified model that employs the full set of controls. As with the results using the special GED subsamples, the estimates based on these racial/ethnic and gender subgroups were very similar to the estimates in Table 4. Finally, and of no surprise given Figures 3 and 4, none of our estimates change if we include math and reading scores as controls in any of the regressions.

\section{Summary and Conclusions}

This study focuses attention on a sample of academically "at risk” students who were enrolled in the $8^{\text {th }}$ grade in Texas public schools in the mid-1990s. After showing that the eventual high school graduates and the eventual GED holders in this group were

very similar in the $8^{\text {th }}$ grade, this study contrasts the postsecondary education outcomes of these two groups as a way of examining the extent to which school dropouts use the GED program as a route to postsecondary education relative to high school graduates. 
Our study confirms some well known facts about academically at-risk students and the education they attain beyond high school. Namely, students who are on the academic margins in the year before high school are more prone to dropout, more likely to be held back a grade in high school, and they tend to have lower levels of postsecondary education enrollment rates than students with a more solid $8^{\text {th }}$ grade foundation. We also found, however, that at-risk $8^{\text {th }}$ graders who graduate with a high school diploma participate in postsecondary education at non-trivial rates. Almost half (46 percent) of the school graduates in our sample who were labeled as “at risk" in the $8^{\text {th }}$ grade had enrolled in some postsecondary education within three years of graduating, and they had enrolled for about two-thirds of a year worth of credits ( 21 credits). While these are lower rates than high school graduates not designated as at-risk $8^{\text {th }}$ graders (67 percent enrollment rates and 40 mean credits), they indicate that many academically marginal students who persist through high school and graduate with a diploma go on to garner some postsecondary education.

We present a less bright story for the $8^{\text {th }}$ grade at-risk students who do not finish high school but drop out and obtain a GED. The unconditional probability of these students enrolling in postsecondary education within three years of obtaining a GED is 29 percentage points lower than the probability for the at-risk high school graduates. A wide array of individual and school level controls (both $8^{\text {th }}$ grade school and last school of attendance), along with school district fixed effects, can only explain about 5 percentage points of this disadvantage. Since the GED holders enroll at lower rates, they also have enrolled for fewer credits, about 40 percent less. However, this difference in enrolled credits is not completely driven by the relatively high percentage of never-enrolled GED 
holders. Even among those who with positive postsecondary education enrollment rates, GED holders have enrolled for substantially fewer credits than the at-risk high school graduates.

While the relatively worse PSE outcomes of the GED holders are consistent with what one would find in the literature on the GED-PSE relationship, this study makes two important contributions to this literature. First, prior to this paper, the question at hand has been "answered" via simple mean comparisons or by OLS regression estimates that have lacked any underlying model that would help us understand and interpret the results. By explicating the sequential decision process from dropping out, to obtaining a GED, to making PSE decisions, the model developed in this paper brings structure to this problem and illuminates the potential biases that could cause us to potentially overstate the negative PSE effects of taking a "GED path" to PSE.

Second, while we do not argue that our estimates are free of bias, we do believe that estimates based on the AR8 sample contain less negative bias than results typically found in the literature. At least on cognitive skill measures that are closely linked to later PSE outcomes, our AR8 sample is very well matched in the year prior to high school entry.

Given the similarities of these two groups when they were in the $8^{\text {th }}$ grade, how can we explain the results in this paper? We examine in turn four different possible explanations.

The Post-GED Horizon in the TSMP Data is Too Short 
As explained earlier, the TSMP data do not provide any postsecondary education information beyond a three year post-GED or post-high-school-diploma window. It could be that given more time, we might see GED holders substantially close the postsecondary educational attainment gap. We can use NELS 88 data to examine this proposition. We first note that if we limit postsecondary education enrollment in a public institution in the NELS 88 data to the same three-year window used in this paper, we get very similar results. In a regression using NELS 88 students who were at-risk in the $8^{\text {th }}$ grade and controlling for gender, race/ethnicity, family structure, parental education level, primary home language, and socioeconomic status (all measured in the $8^{\text {th }}$ grade year), we find that GED holders in the NELS 88 data had a 23.2 percentage point lower probability (pvalue $<0.0001$ ) of having ever enrolled in a public postsecondary education institution within three-years than did high school graduates. Recall that estimates using TSMP data point to a 23.9 percentage point GED disadvantage (Model 5 of Table 4). Thus, results using a three-year window are virtually identical using either NELS 88 or TSMP data though the specifications are slightly different across the two data sets owing to the available control variables in each.

In an identical specification using NELS 88 data that allows for a six-year window, GED holders do close the postsecondary education gap somewhat. If GED holders and high school graduates are allowed six years after graduation or credentialing to garner postsecondary education, the GED disadvantage drops to an 18 percentage point lower probability of having ever enrolled in a public postsecondary education 
institution. ${ }^{16}$ Thus, a longer horizon for observing postsecondary outcomes could explain away some, but not very much, of the GED disadvantage that we observe in the first three post-credential years using TSMP data. ${ }^{17}$

\section{Selection on Unobserved Heterogeneity}

It could be the case that even though our two groups are very similar on observables at "baseline" in the $8^{\text {th }}$ grade, they are either already dissimilar on unobservable dimensions related to postsecondary education outcomes or heterogeneity related to these outcomes emerges over time. In the terms of our model, estimates of the causal effect of taking the "GED path" to PSE suffer from negative bias due to either

$$
\sigma_{G E D, w}>0 \text { or } \sigma_{G E D, z}>0
$$

or both.

While this gives us the econometric solution, there are also implications for policy and practice since this scenario suggests that within the at-risk pool of $8^{\text {th }}$ graders, individuals with low unobserved potential for going on to college systematically select into the "GED path" that includes as a first step, dropping out of school. What are the policy implications of this explanation for our negative GED results?

\footnotetext{
${ }^{16}$ The raw enrollment percentages in NELS after six years are 0.60 for high school graduates and 0.41 for GED holders. This compares to 0.56 for high school graduates and 0.31 for GED holders after three years in the NELS data.

${ }^{17}$ Note that neither can we explain the GED disadvantage by the fact that the TSMP data limits us to public postsecondary education attainment. If we fit the three-year and six-year NELS regressions using enrollment in any postsecondary institution, public or private, the GED-high school gap widens in both cases (-0.28 in the three-year regression and -0.22 in the six year regression). This is because while at-risk GED holders do tend to go to either private, for-profit institutions or private less-than-4-year colleges at slightly higher rates than do at-risk high school graduates (10.9 percent versus 7.9 percent), at-risk high school graduates tend to go to private four-year colleges at much higher rates than do at-risk GED holders (9.2 percent versus 1.6 percent).
} 
To the extent that low college-going potential is largely driven by behavioralbased barriers such as attitudes toward or beliefs about postsecondary education, policies aimed at increasing the postsecondary education attainment of GED holders would have to focus on changing behavior and beliefs rather than improving skills or removing institutional barriers to postsecondary education participation. Difficulties in designing such public policies are easy to imagine, beginning with the fact that barriers connected to individual beliefs and attitudes do not appear in any administrative data in ways that could be used ex ante to determine the optimal mix or targeting of GED-related programs that might improve postsecondary education attainment. Thus, this explanation for the worse PSE outcomes of GED holders suggests a limited, or at the least, not-well-defined role that public policy might play in ameliorating the situation.

The Persistence of the Drop Out "Shock"

As our model demonstrated, we would expect estimates of the causal effect of the "GED path" to be negatively biased if the period $t 1$ exogenous shock had a persistent negative effect on education investment decisions. Thus, even if our use of the AR8 sample meant that

$$
\sigma_{G E D, w}=0 \text { and } \sigma_{G E D, z}=0 \text {, }
$$

any persistent effects of a teenage pregnancy, parental divorce, or family economic hardship that dampened the PSE decisions of GED holders would lend a negative bias to the causal effect of the GED on PSE outcomes. Again the question is, what is the information content here for policy and practice? 
To the extent that these random shocks with persistent effects are responsible for the results we see, rather than unobserved heterogeneity, policies aimed at improving the postsecondary education outcomes of GED holders may be in a somewhat better situation to have a positive impact. At least we would not be expecting adult education policy to change beliefs and attitudes about postsecondary education. On the other hand, it is not clear how to go about designing coordinated and systematic programming that could address the different personal circumstances that would result from the wide variety of negative shocks that could be influencing both the school-leaving and the postsecondary education decisions. Nevertheless, there is potentially more promise in assessing and addressing barriers to postsecondary education participation around tangible issues such as child care, financial aid, or transportation than in trying to alter behavioral-related barriers to further education.

The GED Program Is a Weak Route into Postsecondary Education

A fourth explanation is that our estimates are free of bias and represent the true, negative causal effect of "assignment" the GED path relative to the high school graduation path. That is, this explanation assumes that

$$
\sigma_{G E D, w}=0, \sigma_{G E D, z}=0 \text {, and } \lambda=0 \text {. }
$$

If these strong assumptions hold, then otherwise identical individuals who find themselves in either the GED or the high school graduation path have very different probabilities of going on to postsecondary education. What happened to the dropout who obtained a GED that shifted the college-going probability? What is there about going 
through the GED process relative to finishing the last years of high school that lower GED holders’ probability of obtaining some postsecondary education.

To the extent that our estimates are unbiased and reflect problems within the GED program, then changes in policies and practices of the GED program hold some promise for increasing the postsecondary education outcomes of GED holders. Under this scenario, we would not have to develop programs designed to alter attitudes or beliefs of individuals, nor would we have to address programmatically the great variety of life circumstances that cause a person to drop out and then persist to affect the postsecondary education calculus. In this case, we “only” need to figure out how to redesign or supplement the GED process so that the very fact of using this route to "school completion” as opposed to finishing high school does not negatively alter postsecondary education probabilities.

Of course, this may be a difficult task. For example, it might be that the actual time spent in the last years of high school matriculation positively influence postsecondary education attainment. Perhaps it is the additional human or social capital, or maybe the college guidance one receives in the last years of high school that matter. Perhaps it is the interaction between these and other factors that affects the postsecondary education decisions of students and their families. The issue is that there may be something about "the high school experience" that is difficult, if not impossible, to replicate in the GED setting.

On the other hand, improving the postsecondary education outcomes associated with receipt of a GED might be a relatively straightforward task. Perhaps a substantial difference could be made by de-emphasizing the role of the GED is a "terminal" 
education credential, and shifting the emphasis to using the GED as a route to postsecondary education. Moving to this model would potentially require changes in the perceptions and attitudes of GED administrators, teachers, and students, as well as changes in the formal and informal linkages between GED preparation and testing programs and local postsecondary education institutions. There is evidence that the adult education field has been moving in this direction in recent years as research emphasizing both the relatively weak economic benefits of the GED and the growing economic importance of postsecondary education have become widely disseminated and accepted in the field. We note that the extent to which this "programmatic reform" approach might increase the postsecondary attainment of GED holders depends on both the efficacy of any changes in the GED program as well as the extent to which this last explanation is responsible for the results we see. That is, if the "programmatic" explanation explains only a small part of the results we see, then only small improvements in college-going rates would result from even substantial and effective changes in the GED program.

This study has shown that among at-risk students who look very similar in the $8^{\text {th }}$ grade, individuals who subsequently drop out and obtain a GED acquire substantially less postsecondary education in the first post-credential years than do the high school graduates. Given the importance of postsecondary education in today’s economy and society, this is a fact that should attract public attention. Our closing discussion points to the importance of trying to understand the underlying causes of the discrepancy in outcomes between GED holders and high school graduates. The reason is that both the policy prescriptions and the potential for the success of such prescriptions are very different depending upon whether the observed differences in outcomes are the result of 
behavioral factors related to GED acquisition, persistent negative effects associated with drop-out-inducing shocks, or practices and policies of the GED program itself. Research that could help sort out these explanations could inform public policy, lead to the more efficient use of public monies, and potentially increase the postsecondary education levels of students who are currently at the mercy of an economy that offers few routes to economic stability and self-sufficiency for those lacking any postsecondary education. 


\section{References}

Adelman, Clifford. "The Toolbox Revisited: Paths to Degree Completion from High School through College," Washington, D.C.: U.S. Department of Education, 2006, 192.

Berktold, Jennifer; Geis, Sonya and Kaufman, Phillip. "Subsequent Educational Attainment of High School Dropouts," Washington, D.C.: National Center for Education Statistics, 1998.

Boesel, David; Alsalam, Nabeel and Smith, Thomas M. "Educational and Labor Market Performance of Ged Recipients," Washington, D.C.: Office of Educational Research and Improvement, Dept. of Education, 1998.

Heckman, James J. and Rubinstein, Yona. "The Importance of Noncognitive Skills: Lessons from the Ged Testing Program." American Economic Review, 2001, 91(2), pp. 145-49.

Hexter, Holly and Andersen, Charles J. "Admission and Credit Policies for Adult Learners," Washington, D.C.: American Council on Education, 1986, 25.

Kane, Thomas J. and Rouse, Cecilia. "Labor Market Returns to Two-Year and Four-Year College." American Economic Review, 1995, 85(3), pp. 600-14.

McMillen, Marilyn M. and Kaufman, Phillip. "Dropout Rates in the United States: 1994," Washington, D.C.: United States Department of Education, 1996, 146.

Murnane, Richard J., Willett, John B., and Tyler, John H. "Who Benefits from a Ged? Evidence from High School and Beyond." The Review of Economics and Statistics, 2000, 82(1), pp. 23-37.

Murnane, Richard J.; Willett, John B. and Boudett, Kathryn Parker. "Do Male Dropouts Benefit from Obtaining a Ged, Postsecondary Education, and Training?" Evaluation Review, 1999, 22(5), pp. 475-502.

Murnane, Richard J., Willett, John B., and Boudett, Katherine P. "Does Acquisition of a GED Lead to More Training, Post-Secondary Education, and Military Service for School Dropouts?" Industrial and Labor Relations Review, 1997, 51(1), pp. 10016.

Orr, Larry L. Social Experiments: Evaluating Public Programs with Experimental Methods. Thousand Oaks, CA: Sage Publications, Inc., 1999. 
Texas Education Agency. "1996-97 Report on High School Completion Rates," Austin, Texas, 1999.

Tyler, John. "Does the Ged Improve Earnings? Estimates from a Sample of Both Successful and Unsuccessful Ged Candidates." Industrial and Labor Relations Review, 2004, 57(4), pp. 579-98.

Tyler, John H., Murnane, Richard J., and Willett, John B. "Who Benefits from a Ged? Evidence for Females from High School and Beyond." Economics of Education Review, 2003, 22(3), pp. 237-47.

Tyler, John H.; Murnane, Richard J. and Willett, John B. "Estimating the Labor Market Signaling Value of the Ged." Quarterly Journal of Economics, 2000, 115(2), pp. 431-68. 
Table 1. Distributions of education outcomes of $19888^{\text {th }}$ graders as of December 2000 by type and timing of high school completion status.

\begin{tabular}{|c|c|c|c|c|c|c|c|c|c|}
\hline & $\begin{array}{l}\text { Percent } \\
\text { BA }\end{array}$ & $\begin{array}{l}\text { Percent } \\
\text { AA }\end{array}$ & $\begin{array}{c}\text { Percent } \\
\text { certificate }\end{array}$ & $\begin{array}{l}\text { Percent } \\
\text { no } \\
\text { degree, } \\
\text { still } \\
\text { enrolled }\end{array}$ & $\begin{array}{l}\text { Percent } \\
\text { once } \\
\text { enrolled, } \\
\text { not now }\end{array}$ & $\begin{array}{l}\text { Percent } \\
\text { never } \\
\text { enrolled }\end{array}$ & $\begin{array}{l}\text { Row } \\
\text { total }\end{array}$ & $\begin{array}{l}\text { Percent } \\
\text { ever } \\
\text { enrolled }\end{array}$ & $\begin{array}{l}\text { Percent } \\
\text { never } \\
\text { enrolled }\end{array}$ \\
\hline $\begin{array}{l}\text { On time high } \\
\text { school } \\
\text { graduates* }\end{array}$ & 37.4 & 6.0 & 3.6 & 5.9 & 30.3 & 16.8 & 1.0 & & \\
\hline $\begin{array}{l}\text { Late high } \\
\text { school } \\
\text { graduates }\end{array}$ & 4.3 & 6.5 & 4.3 & 8.7 & 41.3 & 34.8 & 1.0 & & \\
\hline GED holders & 1.2 & 2.4 & 4.9 & 9.8 & 34.1 & 47.6 & 1.0 & & \\
\hline $\begin{array}{l}\text { Uncredentialed } \\
\text { dropouts }\end{array}$ & & & & & & & 1.0 & 13.0 & 87.0 \\
\hline
\end{tabular}

* A student in the $19888^{\text {th }}$ grade cohort graduated “on time" if they graduated by July 1992.

Source: Authors' calculations based on Table L-12, page 175 of Adelman (2006).

${ }^{* *}$ The authors' examination of the roughly 13 percent of uncredentialed dropouts who ever enrolled in a postsecondary institution indicates that about 4 percent had enrolled in private, for-profit institutions and the bulk of the rest had enrolled in 2-year or less than 2-year public institutions. 
Table 2. Descriptive statistics of at-risk $8^{\text {th }}$ graders (AR8 sample) from the $19948^{\text {th }}$ grade cohort who will eventually earn a GED or a high school diploma (standard deviations of continuous variables in parentheses).

\begin{tabular}{|c|c|c|}
\hline & $\begin{array}{c}\text { Eventual } \\
\text { GED } \\
\text { holders }\end{array}$ & $\begin{array}{c}\text { Eventual } \\
\text { high school } \\
\text { graduates }\end{array}$ \\
\hline \multicolumn{3}{|l|}{ Individual level information } \\
\hline Mean age at first day of $8^{\text {th }}$ grade & 13.4 & $13.2^{*}$ \\
\hline Mean $8^{\text {th }}$ grade standardized TAAS math score ${ }^{\mathrm{a}}$ & $\begin{array}{c}-0.233 \\
(0.010)\end{array}$ & $\begin{array}{l}-0.260^{*} \\
(0.008)\end{array}$ \\
\hline Mean $8^{\text {th }}$ grade standardized TAAS reading score ${ }^{\mathrm{b}}$ & $\begin{array}{l}-0.184 \\
(0.012)\end{array}$ & $\begin{array}{l}-0.266^{*} \\
(0.009)\end{array}$ \\
\hline \multicolumn{3}{|l|}{ Percent... } \\
\hline Male & 58.9 & $49.4^{*}$ \\
\hline White & 52.7 & $42.1^{*}$ \\
\hline Black & 11.1 & $20.1^{*}$ \\
\hline Hispanic & 34.6 & 35.7 \\
\hline other race/ethnicity & 1.5 & $2.1^{*}$ \\
\hline economically disadvantaged & 43.6 & 42.8 \\
\hline special education & 6.9 & $13.1^{*}$ \\
\hline English-Second-Language & 1.5 & $4.5^{*}$ \\
\hline in gifted and talented program & 2.3 & $3.5^{*}$ \\
\hline attended $8^{\text {th }}$ grade in large central city & 26.6 & 26.4 \\
\hline attended $8^{\text {th }}$ grade in mid-size central city & 22.4 & $20.7^{*}$ \\
\hline attended $8^{\text {th }}$ grade in urban fringe of large central city & 17.8 & $13.6^{*}$ \\
\hline attended $8^{\text {th }}$ grade in urban fringe of mid-size central city & 3.4 & 3.9 \\
\hline attended 8th grade in large town & 2.1 & 1.8 \\
\hline attended 8th grade in small town & 17.6 & $21.1^{*}$ \\
\hline attended 8th grade in rural locale & 10.1 & $12.5^{*}$ \\
\hline started late or held back a grade before $8^{\text {th }}$ grade & 28.1 & $22.3^{*}$ \\
\hline \multicolumn{3}{|l|}{$8^{\text {th }}$ grade school information ${ }^{c}$} \\
\hline Total students in the school & 851.5 & $824.8^{*}$ \\
\hline Pupil teacher ratio & 16.8 & 16.7 \\
\hline \multicolumn{3}{|l|}{ School percent... } \\
\hline White & 49.6 & $47.0^{*}$ \\
\hline Black & 14.6 & $15.4^{*}$ \\
\hline Hispanic & 33.4 & $35.4^{*}$ \\
\hline on free or reduced lunch & 35.9 & $38.3^{*}$ \\
\hline $\mathrm{N}$ & 6,520 & 11,937 \\
\hline
\end{tabular}

* = GED and high school graduate means are different at the 0.05 level.

a. This statistic is based on the standardized residuals of a regression of the TAAS $8^{\text {th }}$ grade math test score on year-of-attempt dummies using the 4,754 eventual GED holders and the 9,611 eventual high school graduates who have non-missing $8^{\text {th }}$ grade TAAS math scores and who were designated as "at risk" in the $8^{\text {th }}$ grade.

b. This statistic is based on the standardized residuals of a regression of the TAAS $8^{\text {th }}$ grade reading test score on year-of-attempt dummies using the 4,675 eventual GED holders and the 9,600 eventual high school graduates who have non-missing $8^{\text {th }}$ grade TAAS reading scores and who were designated as "at risk" in the $8^{\text {th }}$ grade.

c. All school level information was obtained by merging data from the U.S. Department of Education's Common Core of Data. 
Table 3. Postsecondary education outcomes by education credential and $8^{\text {th }}$ grade at-risk status (standard deviations in parentheses).

\begin{tabular}{|c|c|c|c|c|}
\hline \multirow[b]{2}{*}{ Postsecondary education outcomes } & \multicolumn{2}{|c|}{$\begin{array}{l}\text { At risk in the } 8^{\text {th }} \text { grade } \\
\text { (AR8 sample) }\end{array}$} & \multicolumn{2}{|c|}{ Not at risk in the $8^{\text {th }}$ grade } \\
\hline & $\begin{array}{l}\text { Eventual } \\
\text { GED } \\
\text { holders }\end{array}$ & $\begin{array}{l}\text { Eventual } \\
\text { high } \\
\text { school } \\
\text { graduates }\end{array}$ & $\begin{array}{l}\text { Eventual } \\
\text { GED } \\
\text { holders }\end{array}$ & $\begin{array}{l}\text { Eventual } \\
\text { high } \\
\text { school } \\
\text { graduates }\end{array}$ \\
\hline \multicolumn{5}{|l|}{ Panel A: Full sample } \\
\hline $\begin{array}{l}\text { Percent who... } \\
\text { ever enrolled in a postsecondary } \\
\text { education institution }\end{array}$ & 18.2 & $46.1^{*}$ & 27.1 & $67.4^{*}$ \\
\hline ever earned a postsecondary certificate & 0.7 & $1.8^{*}$ & 0.6 & $1.4^{*}$ \\
\hline ever earned an associates degree & 0.3 & $2.6^{*}$ & 0.5 & $4.0^{*}$ \\
\hline Mean enrolled credits & $\begin{array}{c}5.5 \\
(17.2)\end{array}$ & $\begin{array}{l}21.9^{*} \\
(32.1)\end{array}$ & $\begin{array}{l}10.9 \\
(26.8)\end{array}$ & $\begin{array}{l}40.5^{*} \\
(40.2)\end{array}$ \\
\hline $\mathrm{N}$ & 6,520 & 59,685 & 5,838 & 83,005 \\
\hline \multicolumn{5}{|l|}{ Panel B: Conditional on having ever enrolled } \\
\hline ever earned a postsecondary certificate & 1.6 & 2.7 & 1.3 & $1.6^{*}$ \\
\hline ever earned an associate’s degree & 1.2 & 5.4 & 1.7 & $5.7^{*}$ \\
\hline Mean enrolled credits & $\begin{array}{c}30.5 \\
(29.4)\end{array}$ & $\begin{array}{l}47.5^{*} \\
(31.9)\end{array}$ & $\begin{array}{c}40.2 \\
(38.4)\end{array}$ & $\begin{array}{l}60.1^{*} \\
(35.0)\end{array}$ \\
\hline $\mathrm{N}$ & 1,184 & 5,505 & 1,583 & 11,183 \\
\hline
\end{tabular}

* = within at-risk group GED and high school graduate means are different at the 0.05 level.

Table 4. Estimated postsecondary education outcomes of GED holders relative to the outcomes of high school graduates in a sample of at-risk $8^{\text {th }}$ graders (AR8 sample with standard errors in parentheses).

\begin{tabular}{|c|c|c|c|c|c|c|}
\hline & Model 1 & Model 2 & Model 3 & Model 4 & Model 5 & Model 6 \\
\hline \multicolumn{7}{|l|}{ Dependent variables: } \\
\hline $\begin{array}{l}\text { 1. Ever enrolled in postsecondary } \\
\text { education }\end{array}$ & $\begin{array}{l}-0.290 \\
(0.009)\end{array}$ & $\begin{array}{l}-0.283 \\
(0.009)\end{array}$ & $\begin{array}{l}-0.244 \\
(0.008)\end{array}$ & $\begin{array}{l}-0.244 \\
(0.008)\end{array}$ & $\begin{array}{l}-0.239 \\
(0.008)\end{array}$ & $\begin{array}{l}-0.169 \\
(0.008)\end{array}$ \\
\hline 2. Accumulated credits enrolled & $\begin{array}{c}-17.2 \\
(0.608)\end{array}$ & $\begin{array}{c}-16.5 \\
(0.588)\end{array}$ & $\begin{array}{c}-14.4 \\
(0.525)\end{array}$ & $\begin{array}{c}-14.4 \\
(0.525)\end{array}$ & $\begin{array}{c}-13.9 \\
(0.509)\end{array}$ & $\begin{array}{c}-9.5 \\
(0.491)\end{array}$ \\
\hline $\begin{array}{l}\text { 3. Awarded a certificate or AA } \\
\text { Degree }\end{array}$ & $\begin{array}{l}-0.032 \\
(0.003)\end{array}$ & $\begin{array}{l}-0.033 \\
(0.003)\end{array}$ & $\begin{array}{l}-0.032 \\
(0.003)\end{array}$ & $\begin{array}{l}-0.032 \\
(0.003)\end{array}$ & $\begin{array}{l}-0.032 \\
(0.003)\end{array}$ & $\begin{array}{l}-0.024 \\
(0.003)\end{array}$ \\
\hline \multicolumn{7}{|l|}{ Control variables: } \\
\hline Gender and race/ethnicity & & Yes & Yes & Yes & Yes & Yes \\
\hline $\begin{array}{l}\text { Individual level 8th grade } \\
\text { variables }\end{array}$ & & & Yes & Yes & Yes & Yes \\
\hline School level $8^{\text {th }}$ grade variables & & & & Yes & Yes & Yes \\
\hline $\begin{array}{l}\text { School level variables of last } \\
\text { school attended }\end{array}$ & & & & & Yes & Yes \\
\hline Retained in high school & & & & & & Yes \\
\hline District fixed effects & Yes & Yes & Yes & Yes & Yes & Yes \\
\hline R-squared with dependent variable 1 & 0.11 & 0.12 & 0.22 & 0.22 & 0.23 & 0.25 \\
\hline R-squared with dependent variable 2 & 0.10 & 0.12 & 0.20 & 0.21 & 0.21 & 0.23 \\
\hline R-squared with dependent variable 3 & 0.08 & 0.08 & 0.08 & 0.09 & 0.09 & 0.09 \\
\hline $\mathrm{N}$ & 18,457 & 18,457 & 18,457 & 18,457 & 18,457 & 18,164 \\
\hline
\end{tabular}


Table 5. Distribution of retained grades in high school for students who were "at risk" in the $8^{\text {th }}$ grade (AR8 sample) by education credential. ${ }^{\text {a }}$

\begin{tabular}{|c|c|c|}
\hline & GED holders & $\begin{array}{c}\text { High school } \\
\text { graduates }\end{array}$ \\
\hline $\begin{array}{l}\text { Percent held back in... } \\
9^{\text {th }} \text { grade }\end{array}$ & 69.7 & 56.8 \\
\hline $10^{\text {th }}$ grade & 26.2 & 23.3 \\
\hline $11^{\text {th }}$ grade & 9.7 & 16.1 \\
\hline $12^{\text {th }}$ grade & 1.6 & 10.3 \\
\hline
\end{tabular}

a. Columns sum to more than 100 percent since some students were held back in multiple grades.

Table 6. Postsecondary outcomes by high school retention status and education credential for students who were "at risk" in the $8^{\text {th }}$ grade (AR8 sample).

\begin{tabular}{|c|c|c|c|c|}
\hline \multirow[b]{2}{*}{ Postsecondary education outcome } & \multicolumn{2}{|c|}{ GED holders } & \multicolumn{2}{|c|}{ High school graduates } \\
\hline & $\begin{array}{c}\text { Not retained } \\
\text { in HS }\end{array}$ & $\begin{array}{c}\text { Retained } \\
\text { in HS }\end{array}$ & $\begin{array}{l}\text { Not retained } \\
\text { in HS }\end{array}$ & $\begin{array}{c}\text { Retained } \\
\text { in HS }\end{array}$ \\
\hline $\begin{array}{l}\text { Percent who... } \\
\text { ever enrolled in a postsecondary } \\
\text { education institution }\end{array}$ & 20.2 & 16.4 & 49.9 & 23.6 \\
\hline $\begin{array}{l}\text { ever earned a postsecondary } \\
\text { certificate or AA degree }\end{array}$ & 1.1 & 0.8 & 4.7 & 1.4 \\
\hline Mean credits earned & 6.9 & 4.2 & 24.3 & 7.4 \\
\hline
\end{tabular}

Table 7. Conditional estimates of postsecondary education outcomes by education credential and high school retention status for students who were "at risk" in the $8^{\text {th }}$ grade (AR8 sample and standard errors in parentheses).

\begin{tabular}{|c|c|c|c|}
\hline & $\begin{array}{l}\text { Ever enrolled in } \\
\text { postsecondary } \\
\text { education }\end{array}$ & $\begin{array}{c}\text { Earned a } \\
\text { postsecondary } \\
\text { certificate or } \\
\text { associate's } \\
\text { degree }\end{array}$ & $\begin{array}{c}\text { Accumulatec } \\
\text { enrollment } \\
\text { credits }\end{array}$ \\
\hline GED & $\begin{array}{l}-0.243 \\
(0.010)\end{array}$ & $\begin{array}{l}-0.036 \\
(0.004)\end{array}$ & $\begin{array}{l}-14.3 \\
(0.636)\end{array}$ \\
\hline GED*Retained in high school & $\begin{array}{c}0.158 \\
(0.017)\end{array}$ & $\begin{array}{c}0.026 \\
(0.005)\end{array}$ & $\begin{array}{c}10.1 \\
(0.921)\end{array}$ \\
\hline \multicolumn{4}{|l|}{ Control variables: } \\
\hline Gender and race/ethnicity & Yes & Yes & Yes \\
\hline $\begin{array}{l}\text { Individual level 8th grade } \\
\text { variables }\end{array}$ & Yes & Yes & Yes \\
\hline School level $8^{\text {th }}$ grade variables & Yes & Yes & Yes \\
\hline $\begin{array}{l}\text { School level variables of last } \\
\text { school attended }\end{array}$ & Yes & Yes & Yes \\
\hline Retained in high school & $\begin{array}{c}-0.231 \\
(0.013)\end{array}$ & $\begin{array}{l}-0.029 \\
(0.004)\end{array}$ & $\begin{array}{l}-14.6 \\
(0.790)\end{array}$ \\
\hline District fixed effects & Yes & Yes & Yes \\
\hline R-squared & 0.25 & 0.09 & 0.23 \\
\hline $\mathrm{N}$ & 18,164 & 18,164 & 18,164 \\
\hline
\end{tabular}


Table 8. Estimated postsecondary education outcomes of selected groups of GED holders relative to the outcomes of high school graduates in a sample of at-risk $8^{\text {th }}$ graders (AR8 sample and standard errors in parentheses).

Dependent variables:

1. Ever enrolled in postsecondary education

2. Accumulated credits enrolled

3. Awarded a certificate or AA Degree

Control variables:

Gender and race/ethnicity

Individual level 8th grade variables

School level $8^{\text {th }}$ grade variables

School level variables of last school attended

District fixed effects

R-squared with dependent variable 1

R-squared with dependent variable 2

R-squared with dependent variable 3

\begin{tabular}{|c|c|c|c|}
\hline $\begin{array}{l}\text { whose last } \\
\text { grade was at } \\
\text { least } 11^{\text {th }} \\
\text { grade }\end{array}$ & $\begin{array}{l}\text { whose time } \\
\text { from drop out } \\
\text { to GED was } \\
\text { one year or } \\
\text { less }\end{array}$ & $\begin{array}{l}\text { who scored in } \\
\text { upper quartile } \\
\text { of GED scores }\end{array}$ & $\begin{array}{c}\text { whose last } \\
\text { school } \\
\text { attended was } \\
\text { large, urban } \\
\text { school }\end{array}$ \\
\hline-0.290 & -0.214 & -0.243 & -0.291 \\
\hline$(0.011)$ & $(0.009)$ & $(0.011)$ & $(0.025)$ \\
\hline-16.7 & -13.0 & -14.4 & -19.4 \\
\hline$(0.708)$ & $(0.557)$ & $(0.665)$ & (1.38) \\
\hline-0.033 & -0.033 & -0.030 & -0.026 \\
\hline$(0.004)$ & (0.003) & $(0.004)$ & (0.007) \\
\hline Yes & Yes & Yes & Yes \\
\hline Yes & Yes & Yes & Yes \\
\hline Yes & Yes & Yes & Yes \\
\hline Yes & Yes & Yes & Yes \\
\hline Yes & Yes & Yes & Yes \\
\hline 0.23 & 0.23 & 0.23 & 0.22 \\
\hline 0.21 & 0.22 & 0.21 & 0.23 \\
\hline 0.09 & 0.09 & 0.09 & 0.04 \\
\hline 2,220 & 4,184 & 2,429 & 945 \\
\hline 14,157 & 16,121 & 14,366 & 2,809 \\
\hline
\end{tabular}

Number GED holders

14,157

16,121

14,366

2,809 
Figure 1. Age-corrected $8^{\text {th }}$ grade math score distributions by later education status.

\section{Math Score Distributions by Education Group}

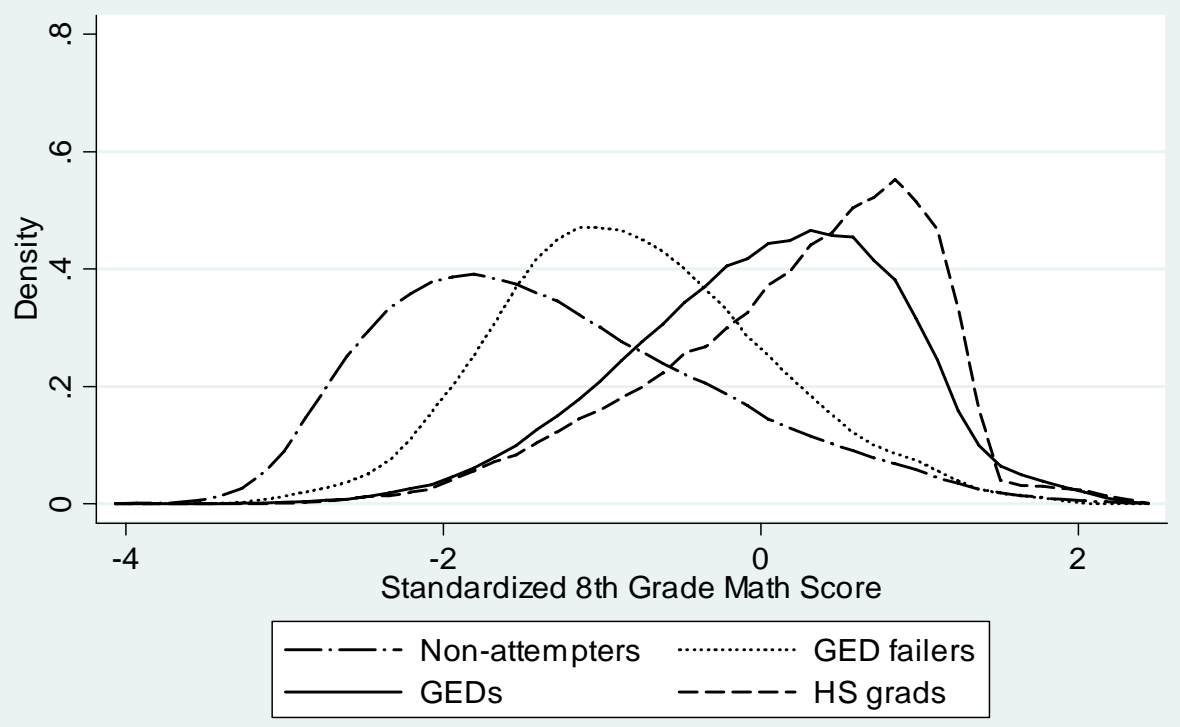

Figure 2. Age-corrected $8^{\text {th }}$ grade reading score distributions by later education status Reading Score Distributions by Education Group

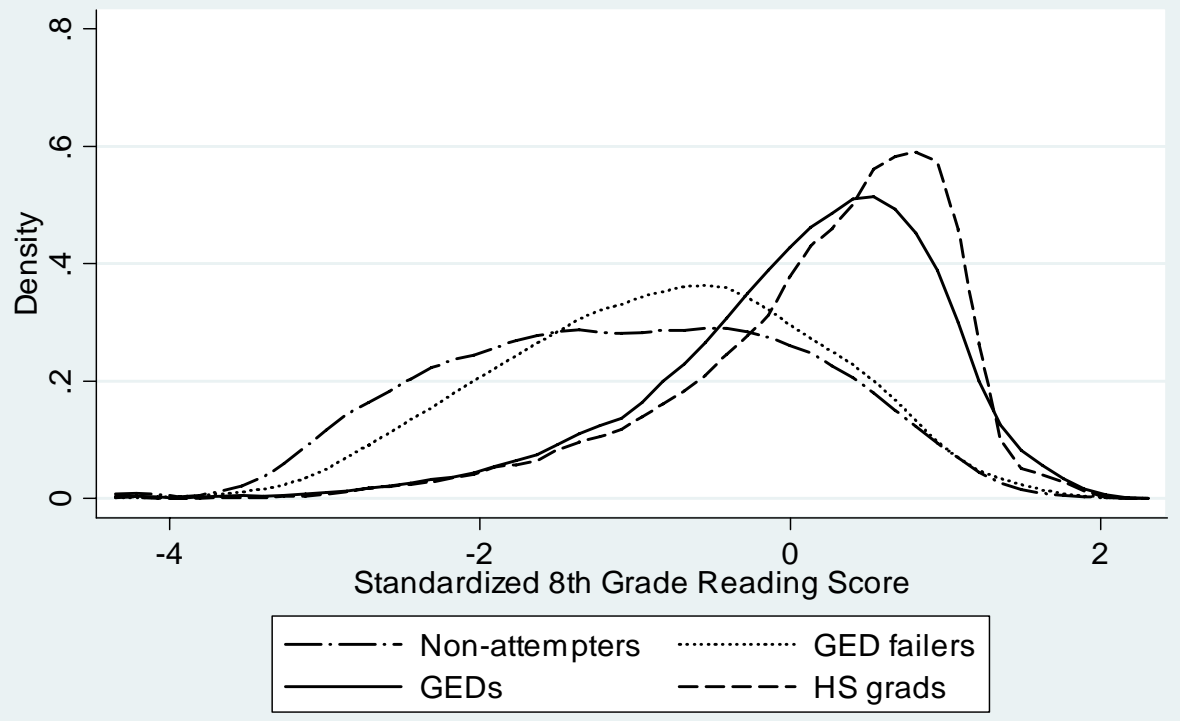


Figure 3. Age-corrected $8^{\text {th }}$ grade math score distributions of at-risk students (AR8 sample) by later education status.

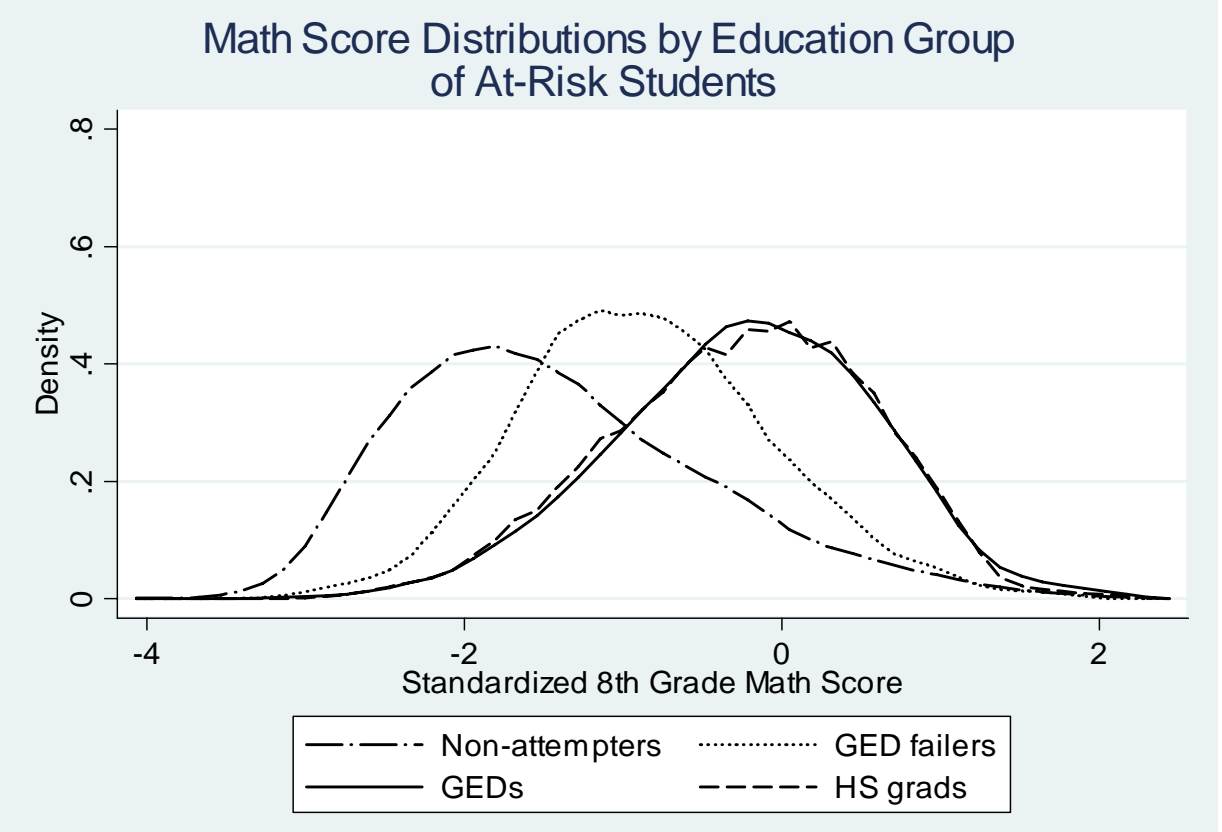

Figure 4. Age-corrected $8^{\text {th }}$ grade reading score distributions of at-risk students (AR8 sample) by later education status.

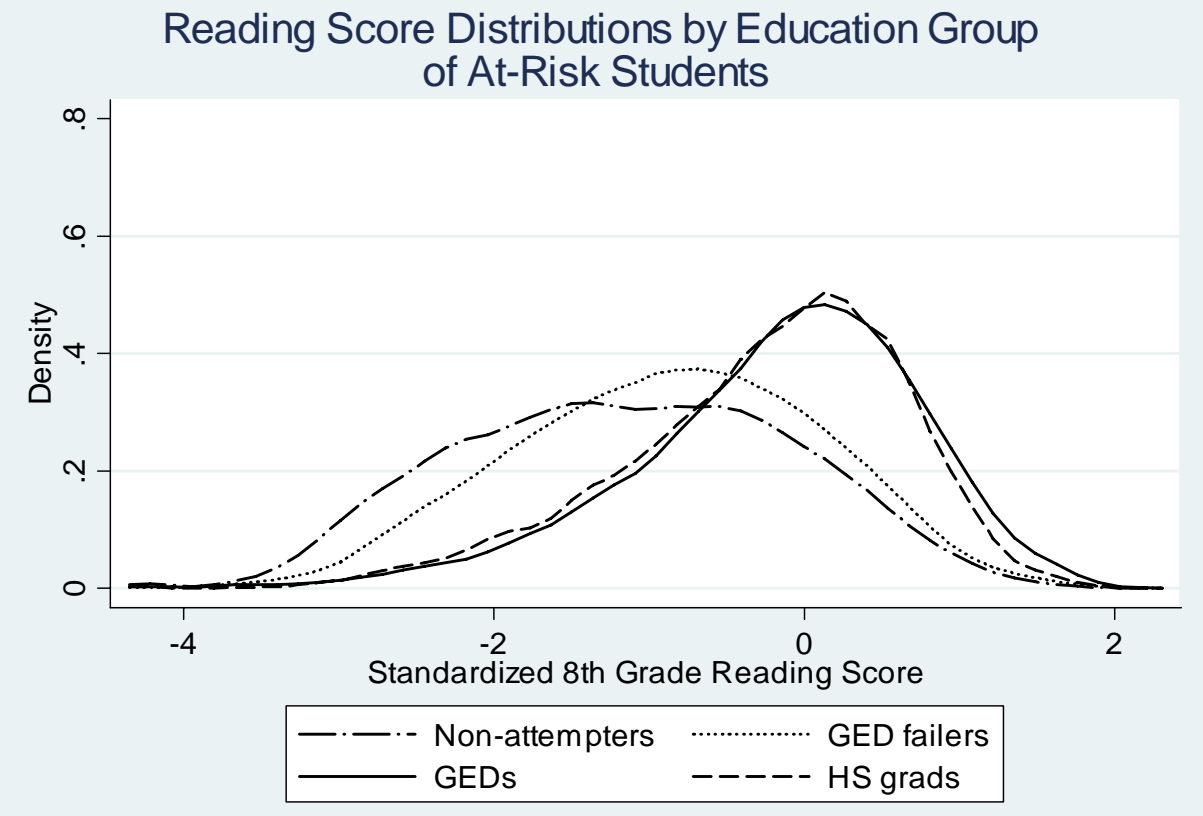


Figure 5 . Age-corrected $8^{\text {th }}$ grade math score distributions by later education status and $8^{\text {th }}$ grade at-risk status.

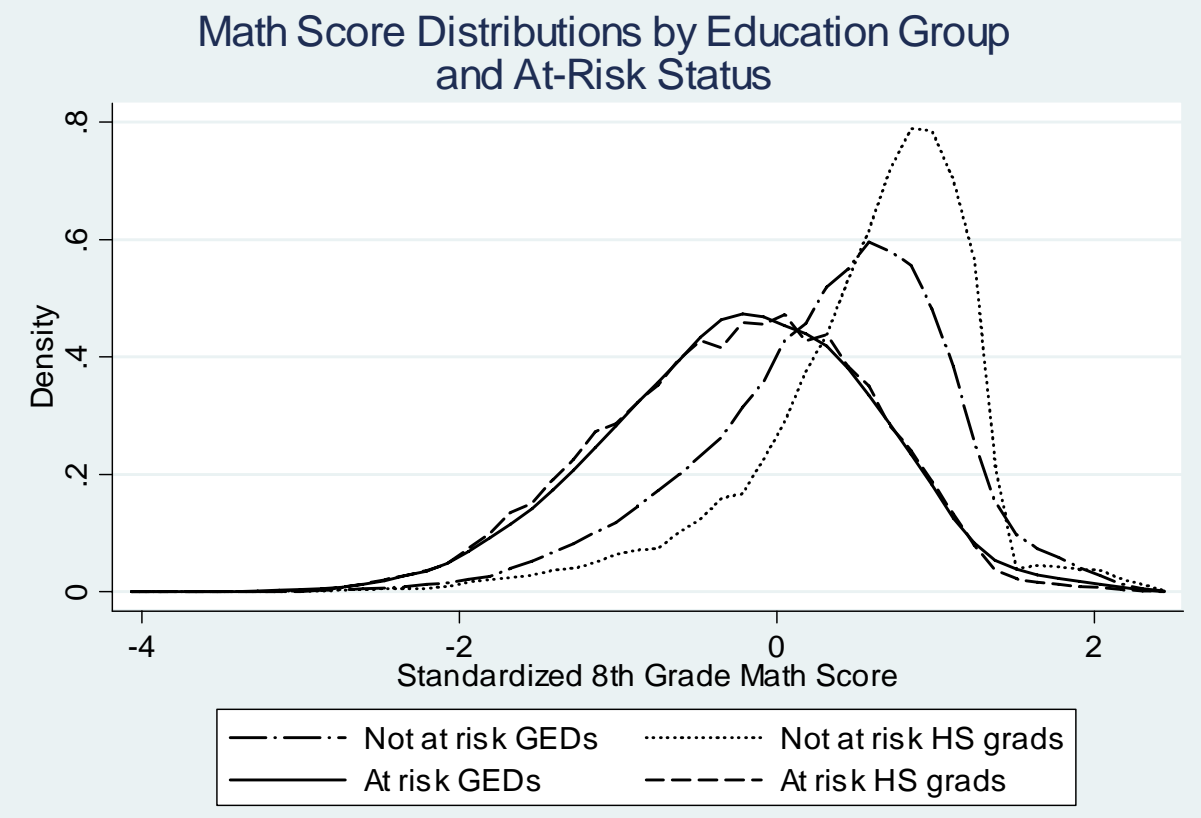

Figure 6 . Age-corrected $8^{\text {th }}$ grade reading score distributions by later education status and $8^{\text {th }}$ grade at-risk status.

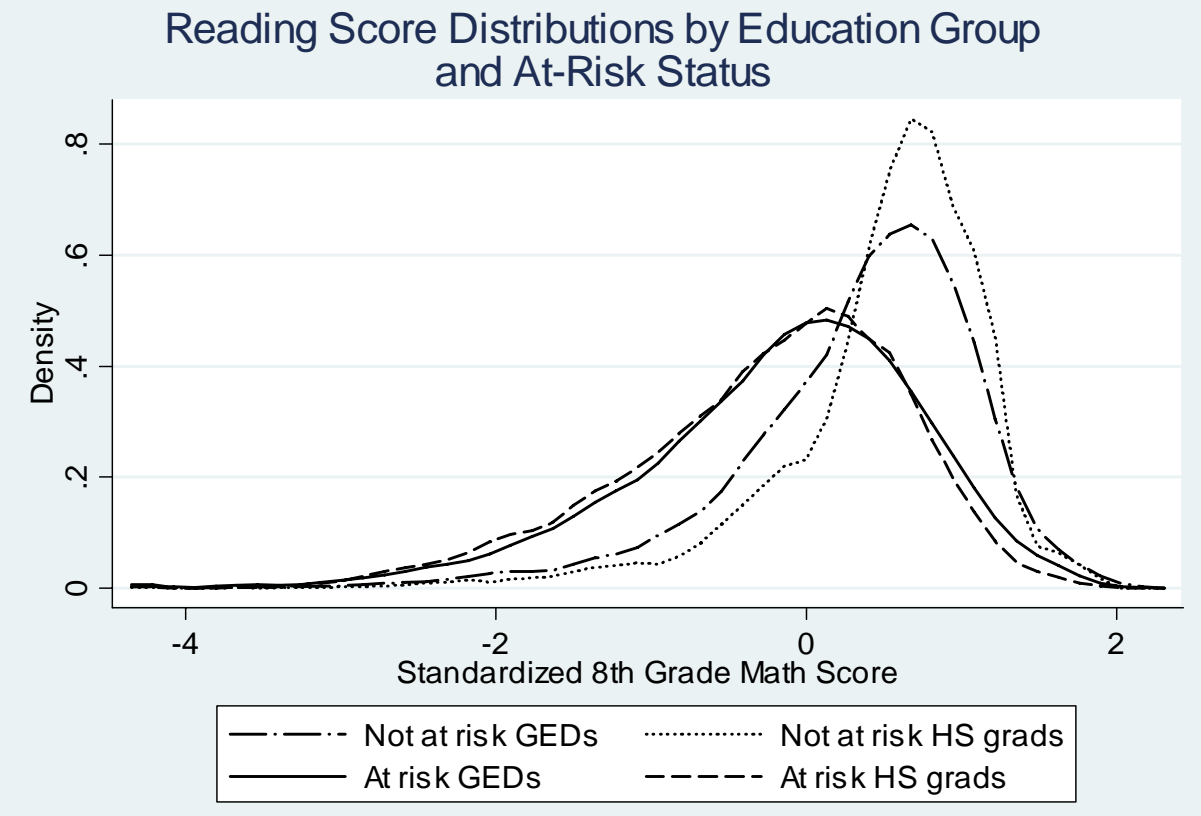


Table A1. Sequential sample selection results for the $19948^{\text {th }}$ grade cohort in the TSMP sample.

\begin{tabular}{|c|c|c|c|}
\hline Row & & GED holders & $\begin{array}{l}\text { Regular high school } \\
\text { graduates }\end{array}$ \\
\hline 1 & Total in 1998 graduation cohort & 20,758 & 36,945 \\
\hline 2 & $\begin{array}{l}\text { Everyone with a valid high school } \\
\text { graduation or GED receipt date }\end{array}$ & 20,757 & 36,767 \\
\hline 3 & $\begin{array}{l}\text { Keep only those GED holders who did not } \\
\text { obtain their GED while in prison }\end{array}$ & 19,467 & 36,767 \\
\hline 4 & $\begin{array}{l}\text { Keep only those GED holders with valid } \\
\text { school leaving date given GED receipt date }\end{array}$ & 18,423 & 36,767 \\
\hline 5 & $\begin{array}{l}\text { Everyone who has valid } 8^{\text {th }} \text { grade } \\
\text { information }\end{array}$ & 15,419 & 32,418 \\
\hline 6 & $\begin{array}{l}\text { Drop individuals who appear as the only } \\
\text { person in a district in the data }\end{array}$ & 15,409 & 32,385 \\
\hline 7 & $\begin{array}{l}\text { Everyone who received a GED or high } \\
\text { school diploma between } 1994 \text { and } 1999\end{array}$ & 13,859 & 31,550 \\
\hline 8 & $\begin{array}{l}\text { Everyone with school-level information on } \\
\text { both their } 8^{\text {th }} \text { grade school and their school } \\
\text { of last attendance before graduating or } \\
\text { dropping out }\end{array}$ & 12,358 & 28,538 \\
\hline 9 & $\begin{array}{l}\text { Students designated as "at risk" in the } 8^{\text {th }} \\
\text { grade }\end{array}$ & 6,520 & 11,937 \\
\hline
\end{tabular}


Table A2. Descriptive statistics of GED holders and high school graduates in the $19948^{\text {th }}$ grade cohort (standard deviations of continuous variables in parentheses).

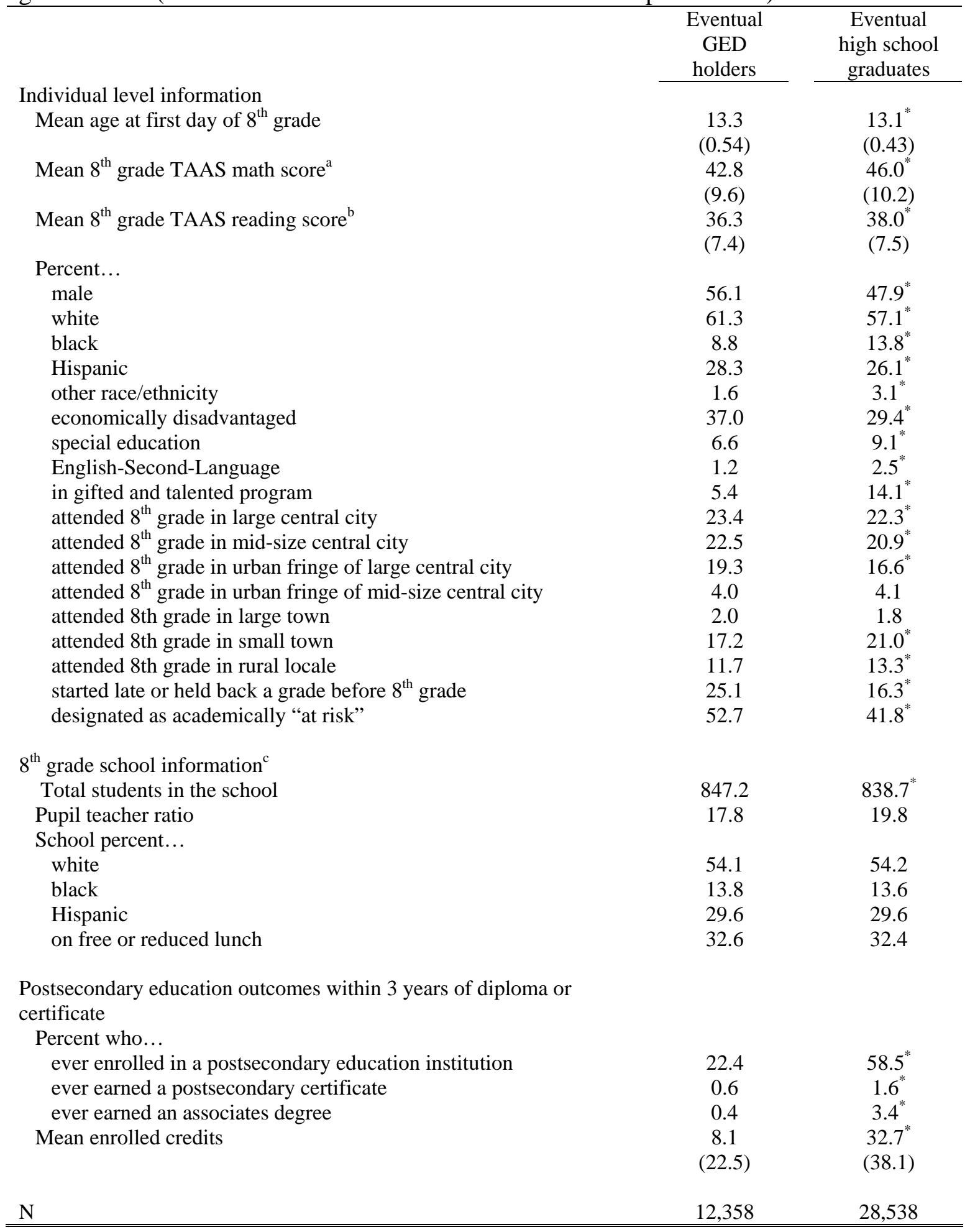

* = GED and high school graduate means are different at the 0.05 level.

a. This statistic is calculated over the 9,040 eventual GED holders and the 23,138 eventual high school graduates with non-missing $8^{\text {th }}$ grade TAAS math scores. 
b. This statistic is calculated over the 8,895 eventual GED holders and 23,141 eventual high school graduates with non-missing $8^{\text {th }}$ grade TAAS reading scores.

c. All school level information was obtained by merging data from the U.S. Department of Education's Common Core of Data. 